Archived version from NCDOCKS Institutional Repository http://libres.uncg.edu/ir/asu/

\title{
Appalacȟnan
}

$\overline{\text { B O O N E, NORT H C A R O L I N A }}$

\section{Dynamics Of The Late Plio-Pleistocene West Antarctic Ice Sheet Documented In Subglacial Diamictites, AND-1 B Drill Core}

\author{
By: Ellen A. Cowan, Poul Christoffersen, Ross D. Powell, and Franco M. Talarico
}

\begin{abstract}
Geologic studies of sediment deposited by glaciers can provide crucial insights into the subglacial environment. We studied muddy diamictites in the ANtarctic geological DRILLing (ANDRILL) AND-1B drill core, acquired from beneath the Ross Ice Shelf in McMurdo Sound, with the aim of identifying paleo-ice stream activity in the PlioPleistocene. Glacial advances were identified from glacial surfaces of erosion (GSEs) and subglacial diamictites within three complete sequences were investigated using lithofacies associations, micromorphology, and quartz sand grain microtextures. Whereas conditions in the Late Pliocene resemble the modern Greenland lce Sheet where fast flowing glaciers lubricated by surface meltwater terminate directly in the sea (interval 201-212 mbsl) conditions in the Late Pleistocene are similar to modern West Antarctic lce Sheet (WAIS) ice streams (38-49 mbsl). We identify the latter from ductile deformation and high pore-water pressure, which resulted in pervasive rotation and formation of till pellets and low relief, rounded sand grains dominated by abrasion. In the transitional period during the Mid-Pleistocene (55-68 mbsf), a slow moving inland ice sheet deposited tills with brittle deformation, producing lineations and bi-masepic and unistrial plasma fabric, along with high relief, conchoidally fractured quartz grains. Changes in the provenance of gravel to cobble-size clasts support a distant source area of Byrd Glacier for fast-flowing paleo-ice streams and a proximal area between Darwin and Skelton Glaciers for the slow-moving inland ice sheet. This difference in till provenance documents a shift in direction of glacial flow at the core site, which indirectly reflects changes in the size and thickness of the WAIS. Hence, we found that fast ice streaming motion is a consequence of a thicker WAIS pushing flow lines to the west and introducing clasts from the Byrd Glacier source area to the drill site. The detailed analysis of diamictites in AND-1 B demonstrates that Pliocene glacial intervals were warmer than in the Pleistocene when polar ice sheets grew from local inland ice to regional ice streams.
\end{abstract}

Cowan, E., Christoffersen, P., Powell, R., \& Talarico, F. (2014). Dynamics of the late Plio-Pleistocene West Antarctic Ice Sheet documented in subglacial diamictites, AND-1B drill core, Global and Planetary Change, Volume 119, 2014, Pages 56-70. https://doi.org/10.1016/i.gloplacha.2014.05.01 1. Publisher version of record available at: https://www.sciencedirect.com/science/article/abs/pii/S0921818114001064 


\title{
Dynamics of the late Plio-Pleistocene West Antarctic Ice Sheet documented in subglacial diamictites, AND-1B drill core
}

\author{
Ellen A. Cowan ${ }^{\mathrm{a}, *}$, Poul Christoffersen ${ }^{\mathrm{b}}$, Ross D. Powell ${ }^{\mathrm{c}}$, Franco M. Talarico ${ }^{\mathrm{d}}$ \\ a Department of Geology, Appalachian State University, Box 32067, Boone, NC 28608, United States \\ b Scott Polar Research Institute, University of Cambridge, Cambridge CB2 1ER, UK \\ c Department of Geology and Environmental Geosciences, Northern Illinois University, DeKalb, IL 60115, United States \\ d Dipartimento di Scienze della Terra, Università di Siena, Via Laterina 8, Siena, Italy
}

\section{A R T I C L E I N F O}

\section{Article history:}

Received 19 December 2013

Received in revised form 30 April 2014

Accepted 27 May 2014

Available online 4 June 2014

\section{Keywords:}

Subglacial till

Deformable bed

Micromorphology

Ice stream

Pleistocene

Ross Sea

\begin{abstract}
A B S T R A C T
Geologic studies of sediment deposited by glaciers can provide crucial insights into the subglacial environment We studied muddy diamictites in the ANtarctic geological DRILLing (ANDRILL) AND-1B drill core, acquired from beneath the Ross Ice Shelf in McMurdo Sound, with the aim of identifying paleo-ice stream activity in the PlioPleistocene. Glacial advances were identified from glacial surfaces of erosion (GSEs) and subglacial diamictites within three complete sequences were investigated using lithofacies associations, micromorphology, and quartz sand grain microtextures. Whereas conditions in the Late Pliocene resemble the modern Greenland Ice Sheet where fast flowing glaciers lubricated by surface meltwater terminate directly in the sea (interval 201$212 \mathrm{mbsl}$ ) conditions in the Late Pleistocene are similar to modern West Antarctic Ice Sheet (WAIS) ice streams (38-49 mbsl). We identify the latter from ductile deformation and high pore-water pressure, which resulted in pervasive rotation and formation of till pellets and low relief, rounded sand grains dominated by abrasion. In the transitional period during the Mid-Pleistocene (55-68 mbsf), a slow moving inland ice sheet deposited tills with brittle deformation, producing lineations and bi-masepic and unistrial plasma fabric, along with high relief, conchoidally fractured quartz grains. Changes in the provenance of gravel to cobble-size clasts support a distant source area of Byrd Glacier for fast-flowing paleo-ice streams and a proximal area between Darwin and Skelton Glaciers for the slow-moving inland ice sheet. This difference in till provenance documents a shift in direction of glacial flow at the core site, which indirectly reflects changes in the size and thickness of the WAIS. Hence, we found that fast ice streaming motion is a consequence of a thicker WAIS pushing flow lines to the west and introducing clasts from the Byrd Glacier source area to the drill site. The detailed analysis of diamictites in AND-1B demonstrates that Pliocene glacial intervals were warmer than in the Pleistocene when polar ice sheets grew from local inland ice to regional ice streams.
\end{abstract}

(C) 2014 Elsevier B.V. All rights reserved

\section{Introduction}

In the stratigraphic record of polar regions, diamicts are commonly interpreted to represent deposits from glacial advances although it is recognized that they may form by a variety of processes in a range of depositional environments. This is especially true in the case of marine terminating glaciers because diamicts can form both subglacially and in ice proximal settings (Carr, 2001; Menzies and Zaniewski, 2003; Hiemstra et al., 2005; Ó Cofaigh et al., 2005; Menzies et al., 2006; Kilfeather et al., 2010; Hambrey and Glasser, 2012). Reconstructions of ice sheet advance, retreat, and glacial thermal regime hinge on the ability to infer depositional processes from a diamict. This is certainly the case in sampling the deep time record with drill cores, where dimensions

\footnotetext{
* Corresponding author.

E-mail addresses: cowanea@appstate.edu (E.A. Cowan), pc350@cam.ac.uk (P. Christoffersen), rpowell@niu.edu (R.D. Powell), talarico@unisi.it (F.M. Talarico).
}

often make it impossible to use clues from macrofabric and structural field relationships. At best, drill cores may be supplemented by seismic reflection profiles and downhole geophysical logs to yield more regionally complete interpretations. Recently, micromorphological analyses from thin sections have become widely recognized as an important additional tool for identifying subglacial deformation (van der Meer et al., 2003; Menzies et al., 2006, 2010; van der Meer and Menzies, 2011).

The dynamic history of the West Antarctic Ice Sheet (WAIS) in the Ross Embayment was recently described from a 1284.87-m-long drill core recording deposition over $13 \mathrm{Ma}$ (Naish et al., 2007, 2009; McKay et al., 2009; Levy et al., 2012; McKay et al., 2012). The drill core, AND1B contains $\sim 58$ geologic sequences, in which advance and retreat of grounded ice are recorded under different styles of glacial and thermal regimes (McKay et al., 2009). The analysis by McKay et al. (2009, 2012) of key glacial and interglacial lithofacies was accompanied by studies of clast provenance (Talarico and Sandroni, 2009; Talarico et al., 2010) and the marine microfossil record (Scherer et al., 2007), 
showing collectively the variable nature of the Antarctic Ice Sheet over time. The geologic record from the core has also provided important constraints for ice sheet modeling (Pollard and DeConto, 2009).

Here our aim is to investigate subglacial conditions by assessing deformation within subglacial tills at scales ranging from 1) macroscopic - based on core description and X-radiography, 2) microscopic - using thin section analyses of skeleton grains and fine-grained matrix (plasma) and 3) scanning electron microscopy (SEM) - to evaluate comminution of quartz grains during glacial transport. Three intervals within AND-1B drill core were selected for study that represent the Late Pleistocene (38-49 $\mathrm{m}$ below sea floor (mbsf)), Mid-Pleistocene (55$68 \mathrm{mbsf}$ ) and Late Pliocene (201-212 mbsf) (Table 1). Each interval has its lower boundary at a glacial surface of erosion (GSE) and encompasses a complete sequence of advance and retreat of the ice sheet over the drill site. Both intervals in the Pleistocene are interpreted as having been deposited during cold periods, when the WAIS advanced and formed the Ross Ice Shelf (McKay et al., 2009, 2012). The Late Pliocene interval was warmer, with Transantarctic Mountain (TAM) glaciers advancing and retreating in open marine environments in the Ross Sea (McKay et al., 2009). However, these paleoenvironmental conditions were inferred from interglacial sediments because the glacial advance deposits appear macroscopically as massive muddy diamictites.

In this study, we analyze diamictites in the AND-1B core at increasingly smaller scales in order to identify different styles of deformation, evaluate water pressure, and infer thermal conditions at the base of the Antarctic Ice Sheet during the last 2.8 Ma. Quartz sand grains were imaged with the SEM from samples collected throughout the core. Dominant sediment sources in the upper $250 \mathrm{~m}$ of the drill core were inferred from the provenance of clasts (diameter $>2 \mathrm{~mm}$ ). Our analysis focuses on diamictite facies located stratigraphically below the associated interglacial retreat facies. This sequence offers the best opportunity for reconstructing paleoglacial conditions at the bed during glacial advances. To gain additional insight, our observations of diamictites in the AND-1B drill core are compared to sedimentary successions of the

Table 1

Summary of glacial and interglacial characteristics of the intervals studied in this paper (chronology according to Wilson et al., 2012).

\begin{tabular}{|c|c|}
\hline \multicolumn{2}{|c|}{ 38-49 mbsf (Late Pleistocene, 0.36-0.43 Ma) } \\
\hline Subglacial thickness & $4.6 \mathrm{~m}$ \\
\hline Subglacial lithofacies & $\begin{array}{l}\text { Sandy-muddy conglomerate, massive clast-rich } \\
\text { diamictite, stratified clast-rich diamictite }\end{array}$ \\
\hline Macroscopic deformation & Sharp angled glacier erosion surface \\
\hline Interglacial thickness & $1.2 \mathrm{~m}$ \\
\hline Interglacial lithofacies & Laminated mudstone, massive silty claystone \\
\hline \multicolumn{2}{|c|}{ 55-68 mbsf (Mid-Pleistocene, 0.53-0.57 Ma) } \\
\hline Subglacial thickness & $7.6 \mathrm{~m}$ \\
\hline Fluctuating grounding-line & $2.9 \mathrm{~m}$ \\
\hline Subglacial lithofacies & $\begin{array}{l}\text { Massive clast-rich diamictite, stratified } \\
\text { clast-rich diamictite }\end{array}$ \\
\hline Macroscopic deformation & $\begin{array}{l}\text { Clasts aligned in shear zone; subtle mixing of } \\
\text { mudstone into overlying diamictite }\end{array}$ \\
\hline Interglacial thickness & $0.8 \mathrm{~m}$ \\
\hline Interglacial lithofacies & $\begin{array}{l}\text { Graded fine to v. fine sandstone, } \\
\text { massive silty claystone }\end{array}$ \\
\hline \multicolumn{2}{|c|}{ 201-212 mbsf (Late Pliocene, 2.8 Ma) } \\
\hline Subglacial thickness & $6.3 \mathrm{~m}$ \\
\hline Subglacial lithofacies & $\begin{array}{l}\text { Massive clast-rich diamictite, stratified } \\
\text { clast-rich diamictite }\end{array}$ \\
\hline Macroscopic deformation & $\begin{array}{l}0.88 \mathrm{~m} \text { thick interval of mixed diamictite and } \\
\text { diatomite, irregular brecciated texture with } \\
\text { discrete lenses and blocks of diatomite } \\
\text { mixed into diamictite }\end{array}$ \\
\hline Interglacial thickness & $\begin{array}{l}12.5 \mathrm{~m}: 8.9 \mathrm{~m} \text { (open marine), } \\
3.6 \mathrm{~m} \text { (ice-proximal glacimarine) }\end{array}$ \\
\hline Interglacial lithofacies & $\begin{array}{l}\text { Open marine: massive and laminated diatomite, } \\
\text { diatomite with dispersed clasts, glacimarine: } \\
\text { stratified diamictite }\end{array}$ \\
\hline
\end{tabular}

LGM in the Ross Sea (Domack et al., 1999; Licht et al., 1999; Shipp et al., 1999; Mosola and Anderson, 2006; Salvi et al., 2006) and diamictons sampled from under modern Antarctic ice streams (Alley et al., 1986, 1989; Tulaczyk et al., 1998; Christoffersen et al., 2010). Our over-arching goal is to describe the paleoglaciological evolution of ice sheets in the Ross Sea during the relatively warm Late Pliocene period and the colder Pleistocene epoch.

\section{Setting}

A 1284.87-m-long sedimentary rock core (AND-1B) was drilled from beneath the northwestern corner of the Ross Ice Shelf $\sim 5 \mathrm{~km}$ from the calving line (Fig. 1). The drill hole is located in the Terror Rift, which lies near the western margin of the larger Victoria Land Basin, one of the three major north-south trending sedimentary basins that form the West Antarctic Rift System of the Ross Embayment (Henrys et al., 2007). The Victoria Land Basin forms one of several north-south trending troughs on the Ross Sea continental shelf, and these troughs are thought to be sites of former ice streams that drained the WAIS and outlet glaciers of the East Antarctic Ice Sheet (EAIS) during the Last Glacial Maximum (Hughes, 1977; Denton and Hughes, 2002; Mosola and Anderson, 2006). The Terror Rift contains $\sim 3.5 \mathrm{~km}$ of sediments, accumulated along its central axis since its inception during the Middle Miocene (Henrys et al., 2007). The sedimentary cycles within AND-1B store information about glacial advances and retreats of a marine-based ice sheet within the Ross Embayment since Miocene (McKay et al., 2009; Naish et al., 2009; McKay et al., 2012). During the Last Glacial Maximum an ice sheet extended across the continental shelf of the Ross Embayment and was supplied by ice from both East and West Antarctica (Denton and Hughes, 2002; Licht et al., 2005). Provenance studies of granule-to cobble-sized clasts incorporated into AND-1B diamictites indicate that subglacial ice was sourced from EAIS outlet glaciers of South Victoria Land, to the south of the drill site (Talarico and Sandroni, 2009; Talarico et al., 2010). Today the Ross Ice Shelf ends near Ross Island and two-thirds of its ice is supplied from the WAIS with the remaining ice coming from EAIS outlet glaciers (Fig. 1; Fahnestock et al., 2000). The core chronology used in this paper is based on the AND-1B age model developed from ${ }^{40} \mathrm{Ar} /{ }^{39} \mathrm{Ar}$ dates, microfossil biostratigraphy, and magnetostratigraphy (Wilson et al., 2012). In addition, the two glacial advance and retreat sequences in the Pleistocene have been correlated to marine isotope stages (MIS) 9-10 and 13-14 by McKay et al. (2012) and the age of the Late Pliocene sequence has been dated to $\sim 2.8$ Ma by Levy et al. (2012).

\section{Methods}

\subsection{Lithofacies descriptions}

This study focuses on three strategic time intervals each containing a complete glacial-interglacial sequence between two GSEs. All undisturbed cores within each interval were X-rayed at the Antarctic Marine Geology Research Facility in Tallahassee, Florida. The radiographs were then printed to scale and used along with the initial sedimentologic description to draft a lithofacies log at a cm-scale (Fig. 2). The X-rays were especially useful in identifying contacts between facies, sedimentary structures and the presence and orientation of clasts not observed on the split core surface.

\subsection{Micromorphology}

Rock slabs were cut for 18 large thin sections $(45 \times 60 \mathrm{~mm})$ from diamictite beds within the study intervals. Thin sections were oriented with respect to vertical but their orientation relative to the ice flow direction is unknown. Friable samples were impregnated with epoxy (Petropoxy 154) before being sectioned. Thin sections were scanned on a high-resolution flatbed scanner to produce a digital low-magnification 

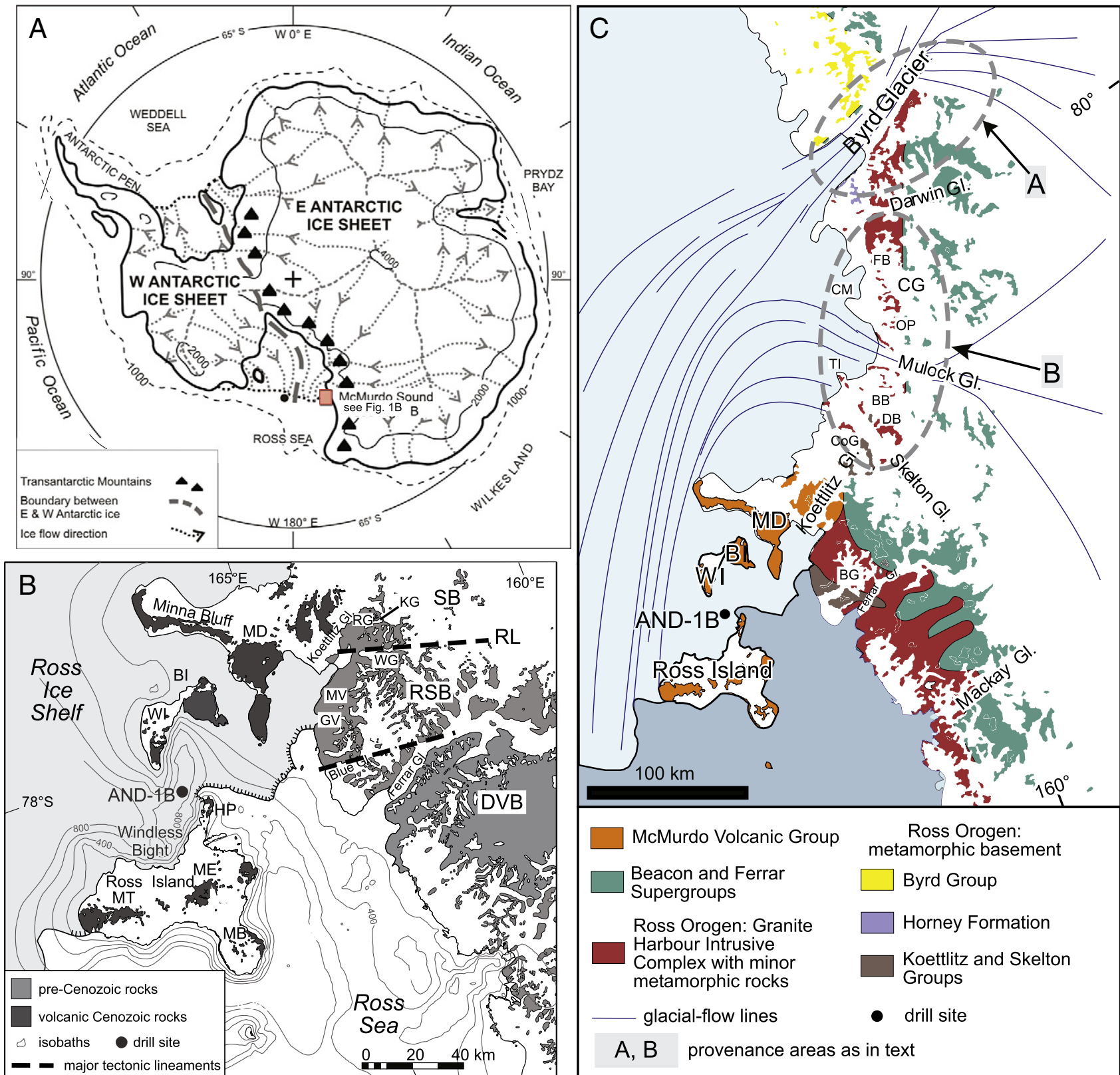

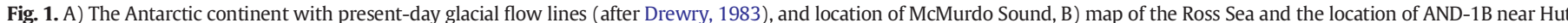

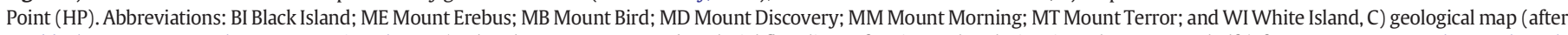

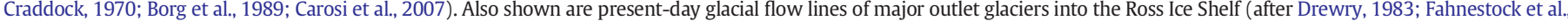
2000). Provenance areas A and B, identified in this paper are shown with dashed circles.

image of the entire slide. Thin sections were also examined using a low magnification petrographic microscope under plane and cross-polarized light with an attached camera system. Terminology used in thin section description follows standard description of microstructures in the glacial literature (i.e., van der Meer, 1993; Carr et al., 2000; van der Meer et al., 2003).

\subsection{SEM imaging}

Bulk samples (15-20 cc) within diamictite units were cut from the core. In the laboratory, these samples were disaggregated as gently as possible by covering with distilled water in a plastic beaker, applying a vacuum to draw water into the pore spaces, and freezing. Upon thawing, the sample fell apart into its constituent grains or the process was repeated until it did. Samples were then sieved and quartz grains picked for imaging using a binocular microscope. Samples of sand grains from 20 depths within AND 1-B were imaged on a Quanta FEI 200 SEM in high vacuum mode at $20 \mathrm{kV}$. Grains were mounted on aluminum stubs and coated with gold. Each grain was identified as quartz using energy dispersive X-ray (EDX) before a photomicrograph was taken. At least 25 grains (cf. Mahaney, 1995; Vos et al., 2014) were examined from the $250-\mu \mathrm{m}$ to $2 \mathrm{~mm}$ sand fraction of each sample. The photomicrograph of each grain was evaluated for the presence of microtextures that commonly occur on glacially transported grains using the technique adapted from Mahaney (2002) and used in Cowan et al. (2008). The microtextures were then categorized into grain 'styles' that can be used to indicate modes of subglacial transport (Hart, 2006).

\subsection{Petrographic study of the gravel fraction}

The composition, dimension and shape of clasts with an average diameter exceeding $2 \mathrm{~mm}$ (i.e., granule to cobble) were determined on 

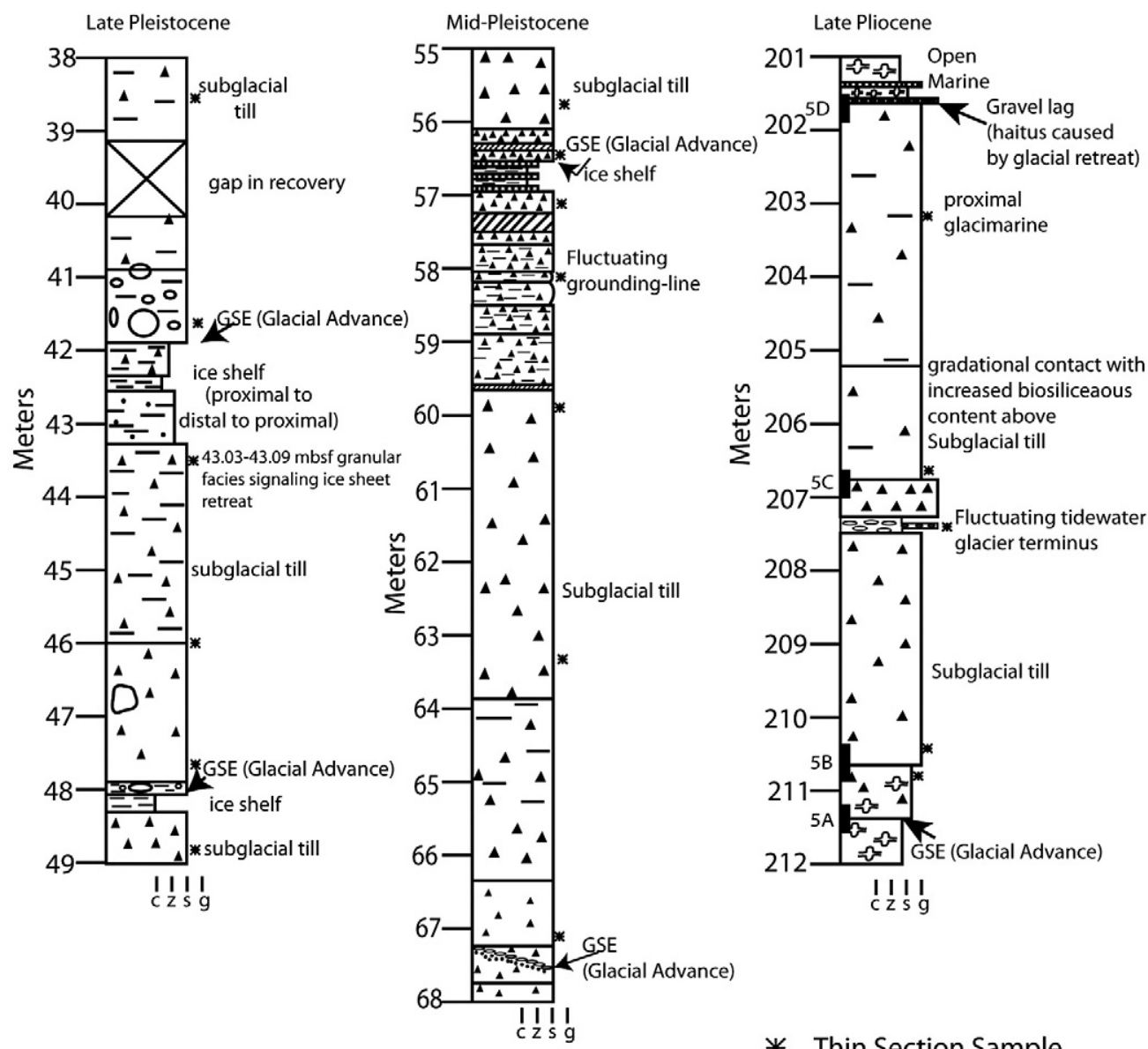

\begin{tabular}{|l|l}
\hline$\Delta$ & Massive \\
\hline & Clast-rich diamictite
\end{tabular}

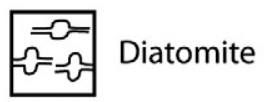

\section{* Thin Section Sample}

\section{$\underline{\Delta} \boldsymbol{\Delta} \boldsymbol{\Delta}$ Stratified clast-rich diamictite}

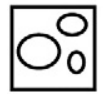

Sandy-muddy conglomerate

\section{\begin{tabular}{|lll}
\hline & $\Omega$ & Mixed diamictite \\
$\Lambda$ & \& diatomite
\end{tabular}}

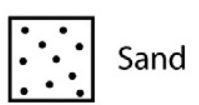

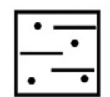

Laminated Mudstone

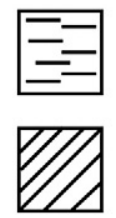

Massive silty claystone

Clast $>$ core

diameter

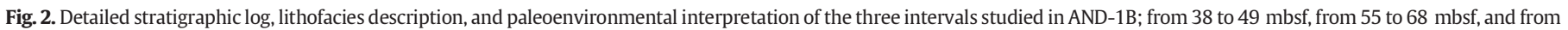
201 to 212 mbsf. A glacial sequence is shown bounded by a glacial surface of erosion (GSE) caused by glacial advance.

the working half of the split core surface. Identification of six major lithological groups (volcanic rocks, intrusive rocks, metamorphic rocks, sedimentary rocks, dolerites, and quartz) was based on distinctive macroscopic features, and confirmed by microscopic analysis on selected clasts (e.g., Pompilio et al., 2007). Data processing involved summation of all clasts from the different compositional groups per $10 \mathrm{~cm}$ and per 1 moving meter of core length. The term "basement clast" is used here to refer to extrabasinal clasts sourced from the pre-Devonian crystalline basement presently exposed in the TAM west and south of the AND1B drill site. The Ferrar and Beacon Supergroups are excluded from this class. Identification of source rock units for basement pebbles was based on (1) detailed petrographic investigations on all cobbles or pebbles large enough to allow a complete mineralogical and textural analysis using a standard thin section; and (2) a sample-to-sample comparison of all investigated clasts with approximately 1500 samples collected from $\sim 70$ outcrops in Southern Victoria Land and central TAM (stored at the Core Repository of the Museo Nazionale dell'Antartide, Siena, Italy).

\section{Results}

We have integrated our data at various scales and present it stratigraphically within the three study intervals to facilitate comparison of the subglacial deposits (Table 1 ). In addition, we present clast lithologies and SEM microtextures on grains sampled from throughout the core.

\subsection{Late Pleistocene (MIS 9-10, 0.36-0.43 Ma)}

\subsubsection{Description}

Cowan et al. (2012) previously described this interval of drill core and it is included here for comparison with the other sections. The GSEs that occur at 47.7 and 41.9 mbsf are sharp and irregular and separate silty claystone or mudstone from sandy muddy conglomerate above (Table 1; Fig. 2). Beginning at 47.7 mbsf a 4.6 m-thick subglacial deposit grades upward from sandy muddy conglomerate to massive clast-rich muddy diamictite, and into weakly stratified clast-rich 
muddy diamictite (Fig. 2) These diamictites have homogenous particle size distribution, an absence of diatoms (completely lacking biosiliceous fragments), and have uniform density and magnetic susceptibility (Niessen et al., 2007; Scherer et al., 2007; McKay et al., 2009). The clay fraction finer than 10 phi averages $26 \%$ of the samples within the muddy diamictite (McKay et al., 2009). Clast content is variable with a higher concentration and more uniform distribution toward the base of the massive diamictite unit. Toward its top, the diamictite becomes weakly stratified with clast-rich facies interbedded with clast-free muddy facies. Clasts are aligned with their long axes parallel to the bedding plane.

All thin sections from these diamictites show evidence of rotational deformation in the form of skelsepic plasma fabric, and circular alignment of skeleton grains (cf. van der Meer, 1993) (Table 2, Fig. 3A, B). In addition, bulk samples and thin sections collected from all subglacial facies within this interval are dominated by competent sand-size aggregate grains described by Cowan et al. (2012) as till pellets. Till pellets are rounded, spherical to prolate in form and are associated with turbate structures (orienting of small grains around larger grains) and lineations in thin sections (Table 2). The core of a pellet may be either a lithic grain or stiff till and additional clay plastered parallel to the pellet edge forms skelsepic plasma fabric (Fig. 3A, B). Till pellets are also associated with well-sorted fine-grained zones within the diamictite (Fig. 3B).

\subsubsection{Interpretation}

Rounded till pellets and turbate structures show pervasive rotational deformation and a lack of grain fractures within the till indicating ductile deformation (cf. Menzies, 2000). This is similar to observations from basal till under the modern Whillans Ice Stream (Tulaczyk et al., 1998; Khatwa and Tulaczyk, 2001). Rotational structures have been reported as a characteristic of deforming beds (van der Meer, 1997; van der Meer et al., 2003; Evans et al., 2006), with increasing strain reflected by an increasing number of turbate forms (Hiemstra and Rijsdijk, 2003).

Previously, we presented two models by which till pellets could form in situ within a highly porous deformable bed near the grounding line of an ice stream (Cowan et al., 2012). In a mechanical shearing model, fractures form in the till as an ice stream advances. Subsequent basal melting and high pore water pressure develop as the ice stream thickens, decreasing the intergranular effective stress inducing rotation of the angular till aggregates as the ice moves over the till. A thermal model, relies on basal freezing with preferential ice growth in larger pore spaces causing rotation of till aggregates due to concentration of shear stresses in a thin zone beneath the glacier sole.

In both models, till pellets are preserved in the subglacial till because deformation of the till is limited to a thin zone spanning only a few centimeters beneath the ice base, as observed beneath the modern WAIS (Engelhardt and Kamb, 1998) and because this deformation zone moves upward as the till layer forms. Active sedimentation should thus help preserve till pellets. However, based on our model, significant transport distance may be limited by the thermal regime in which till pellets form where fast ice streaming motion advects cold ice from the ice sheet interior, resulting in cold basal conditions and formation of a basal ice layer (Christoffersen et al., 2010). Thus till pellets can be transported englacially before melting out when the ice stream eventually thickens or if frictional heating at the bed increases in response to strengthening of the till. This process is likely connected to the observation of a $6 \mathrm{~cm}$-thick granular bed within this interval enriched in till pellets that melted out in the grounding zone marking the transition from subglacial till to sub-ice shelf deposits (Fig. 2), a facies also observed in the Ross Sea (cf. Domack et al., 1999). Till pellets formed mechanically are less likely to be associated with significant transport distances due to the limited vertical extent of till deformation. The provenance of till pellets should therefore help distinguish whether till pellets were formed thermally or mechanically.

\subsection{Mid-Pleistocene (MIS 13-14, 0.53-0.57 Ma)}

\subsubsection{Description}

This interval includes a thick massive diamictite $(7.6 \mathrm{~m})$, succeeded by stratified diamictite $(2.9 \mathrm{~m})$ and then a $<1 \mathrm{~m}$-thick interval composed of laminated mudstone and massive claystone (Table 1, Fig. 2). The GSE occurs over a $\sim 40 \mathrm{~cm}$ interval at $67.1 \mathrm{mbsf}$ and is indicated by clasts inclined at a $20^{\circ}$ angle. At $56.47 \mathrm{mbsf}$ the upper GSE shows subtle mixing of irregular patches of mudstone into the overlying diamictite. Between these are both stratified and massive clast-rich muddy diamictite with a clay fraction finer than 10 phi averaging $28 \%$ of the samples (McKay et al., 2009). Stratification in the diamictite is produced by alternating clast-rich beds and clast-free mudstone beds from 1.5 to $3 \mathrm{~cm}$-thick. Long axes of clasts are random or oriented with their axes parallel to stratification. Massive diamictites are of similar composition but clasts are dispersed throughout the core. Above $60 \mathrm{mbsf}$ there are three clasts that exceed the diameter of the core (Fig. 2). Above the diamictites are graded sandstone beds and massive

Table 2

Summary of micromorphological characteristics in thin sections analyzed in this study.

\begin{tabular}{|c|c|c|c|c|c|c|c|c|c|c|c|c|c|c|}
\hline \multicolumn{6}{|l|}{ Skeleton grains } & \multicolumn{4}{|c|}{ Deformation structures } & \multicolumn{5}{|c|}{ Plasma fabric } \\
\hline Depth (mbsf) & $\begin{array}{l}\text { Litho facies } \\
\text { code }\end{array}$ & $\begin{array}{l}\text { Dominant } \\
\text { grain } \\
\text { size } \mu \mathrm{m}\end{array}$ & $>500 \mu \mathrm{m}$ & $<500 \mu \mathrm{m}$ & $\begin{array}{l}\text { Till } \\
\text { pellets }\end{array}$ & Rotation & Lineations & Fluidization & $\begin{array}{l}\text { Pressure } \\
\text { shadow }\end{array}$ & Skelsepic & Lattisepic & Omnisepic & Bi-masepic & Unistrial \\
\hline $38.78-38.82$ & Dms & $<500$ & SA & $A$ & $\mathrm{X}$ & $\mathrm{X}$ & $\mathrm{X}$ & & & $\mathrm{X}$ & & & & \\
\hline $41.63-41.67$ & Csm & $>500$ & $\mathrm{R}$ & SA & $\mathrm{X}$ & $\mathrm{X}$ & $\mathrm{X}$ & & & $\mathrm{X}$ & & & & \\
\hline $43.94-43.98$ & Dms & $<500$ & SA & A & $\mathrm{X}$ & $\mathrm{X}$ & $\mathrm{X}$ & & $\mathrm{X}$ & $\mathrm{X}$ & & & & \\
\hline $46.25-46.32$ & $\mathrm{Dmm}$ & $>500$ & SA & A & $\mathrm{X}$ & $\mathrm{X}$ & $\mathrm{X}$ & & $\mathrm{X}$ & $\mathrm{X}$ & & & & \\
\hline $47.66-47.70$ & $\mathrm{Dmm}$ & $>500$ & SR & A & $\mathrm{X}$ & $\mathrm{X}$ & $\mathrm{X}$ & & & $\mathrm{X}$ & & & & \\
\hline $48.83-48.90$ & Dms & $>500$ & SR & A & $\mathrm{X}$ & $\mathrm{X}$ & $\mathrm{X}$ & $\mathrm{X}$ & & $\mathrm{X}$ & & & & \\
\hline $55.97-56.04$ & $\mathrm{Dmm}$ & $>500$ & SR & A & $\mathrm{X}$ & $\mathrm{X}$ & $\mathrm{X}$ & & & $\mathrm{X}$ & & & & \\
\hline $56.40-56.47$ & $\mathrm{Dmm}$ & $>500$ & SR & SR & & $\mathrm{X}$ & $\mathrm{X}$ & & & $\mathrm{X}$ & & & & \\
\hline $57.01-57.08$ & $\mathrm{Dmm}$ & $>500$ & SR & SA & $\mathrm{X}$ & $\mathrm{X}$ & $\mathrm{X}$ & $\mathrm{X}$ & $\mathrm{X}$ & $\mathrm{X}$ & & & & \\
\hline $58.21-58.28$ & Dms & $>500$ & SR & SR & & & $\mathrm{X}$ & & & & & & $\mathrm{X}$ & \\
\hline $59.90-59.95$ & $\mathrm{Dmm}$ & $>500$ & SR & SA & & & $\mathrm{X}$ & & & & & & $\mathrm{X}$ & \\
\hline $63.44-63.51$ & $\mathrm{Dmm}$ & $>500$ & SR & SR & & & $\mathrm{X}$ & & & & & & & $\mathrm{X}$ \\
\hline $67.12-67.20$ & Dms & $>500$ & SA & SA & & & $X$ & $X$ & & & & & & $\mathrm{X}$ \\
\hline $203.18-203.26$ & $\mathrm{Dmm}$ & $>500$ & SR & SA & & & & & & & & $\mathrm{X}$ & & \\
\hline $206.83-206.90$ & $\mathrm{Dmm}$ & $>500$ & SR & SR & & & $\mathrm{X}$ & & & & $\mathrm{X}$ & & & \\
\hline 207.37-207.44 & Dms & $>500$ & SA & SA & & & $\mathrm{X}$ & & & & $\mathrm{X}$ & & & \\
\hline $210.45-210.52$ & Dms & $>500$ & SR & SA & & $\mathrm{X}$ & $\mathrm{X}$ & & $\mathrm{X}$ & & & & $\mathrm{X}$ & \\
\hline 210.67-210.75 & $\mathrm{Dmm}$ & $<500$ & SA & SR & & $\mathrm{X}$ & $\mathrm{X}$ & & & & & & & $\mathrm{X}$ \\
\hline
\end{tabular}

Dms = weakly stratified muddy diamictite, $\mathrm{Dmm}=$ massive muddy diamictite, $\mathrm{Csm}=$ sandy muddy conglomerate, $\mathrm{R}=$ rounded, $\mathrm{SR}=$ subrounded, $\mathrm{A}=$ angular, $\mathrm{X}=$ present. 

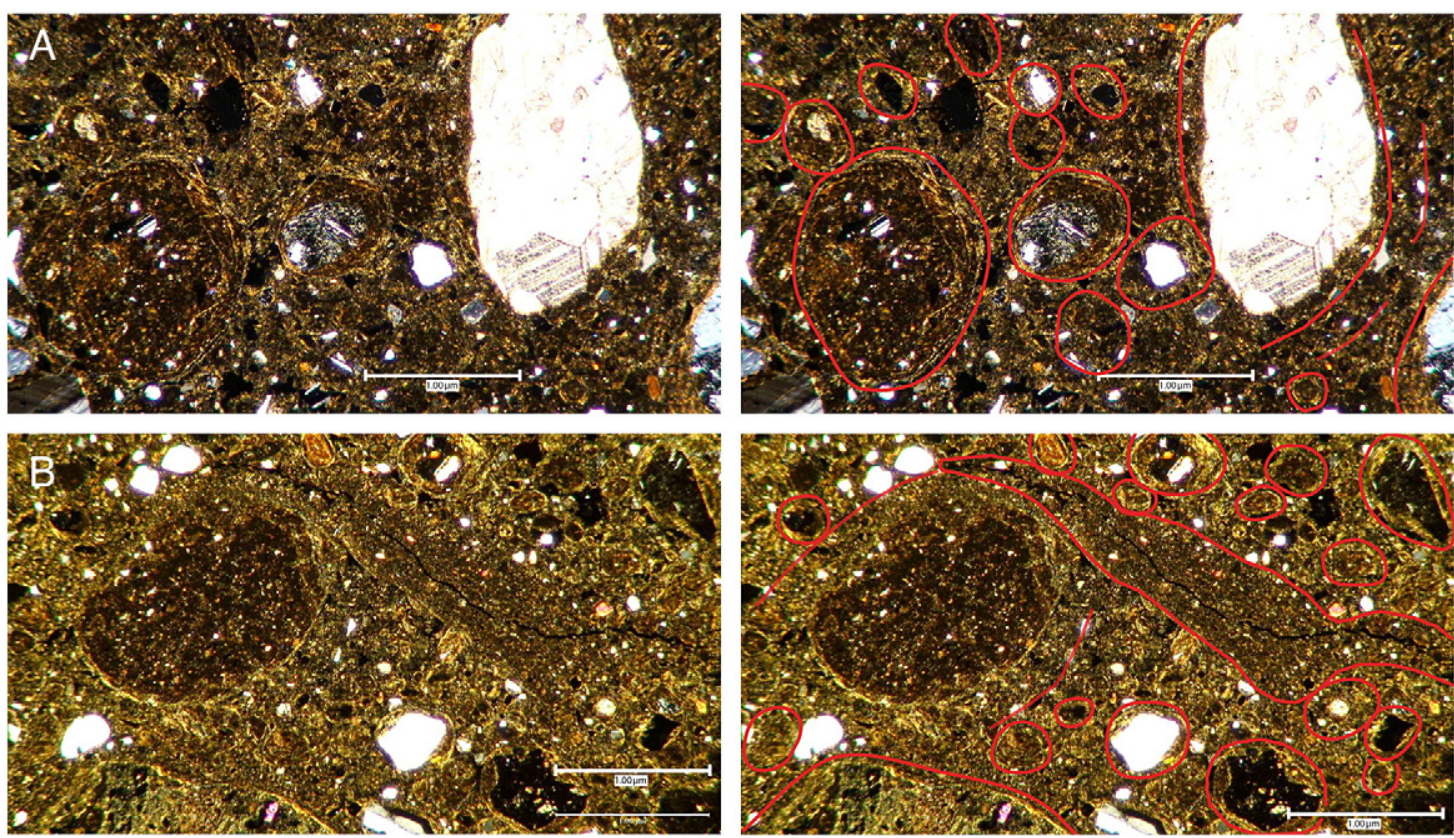

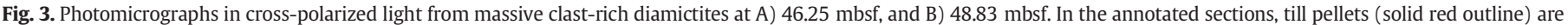
present at each depth as well as a fine-grained fluidized zone outlined in B. Scale bar $=1 \mathrm{~mm}$.

silty claystone. The transition is marked by clayey siltstone draping clasts within the underlying diamictite. Sandstone beds contain volcanic glass and sparse diatom and sponge spicule fragments are present in the silty claystone.

Seven thin sections (TS) are used to assess the micromorphology of the lower diamictites (Table 2). Two TS, bracketing the GSE at top of the section contain till pellets and skelsepic plasma fabric. The lower ones were dominated by lineations and bi-masepic (plasma fabric oriented in bands in two directions) or unistrial (bands oriented in one direction) plasma fabric. TS 58.21-58.28 is stratified muddy diamictite (Fig. 4A) and shows strong alignment of clasts that coincide with the directions of the bi-masepic plasma fabric. TS 59.90-59.95 is in the massive muddy diamictite and shows similar high-angle clast alignment and bi-masepic plasma fabric (Fig. 4B). TS 63.44-63.51, also from massive diamictite has unistrial plasmic with weaker clast alignment than the thin section from $\sim 3.5 \mathrm{~m}$ higher in the core (Fig. 4C). TS 67.1267.20 mbsf was collected from the zone of deformation visibly associated with the GSE (Fig. 2). This thin section has unistrial plasmic fabric accompanied by separation of coarse and fine grains into distinct bands (Fig. 4D). These bands are strongly developed and persist for $\sim 5 \mathrm{~mm}$ across the field of view.

\subsubsection{Interpretation}

This interval occurs within a section of core that is interpreted as ice sheet advance at the lower GSE and deposition of subglacial till and retreat to an ice shelf with preservation of distal ice shelf deposits
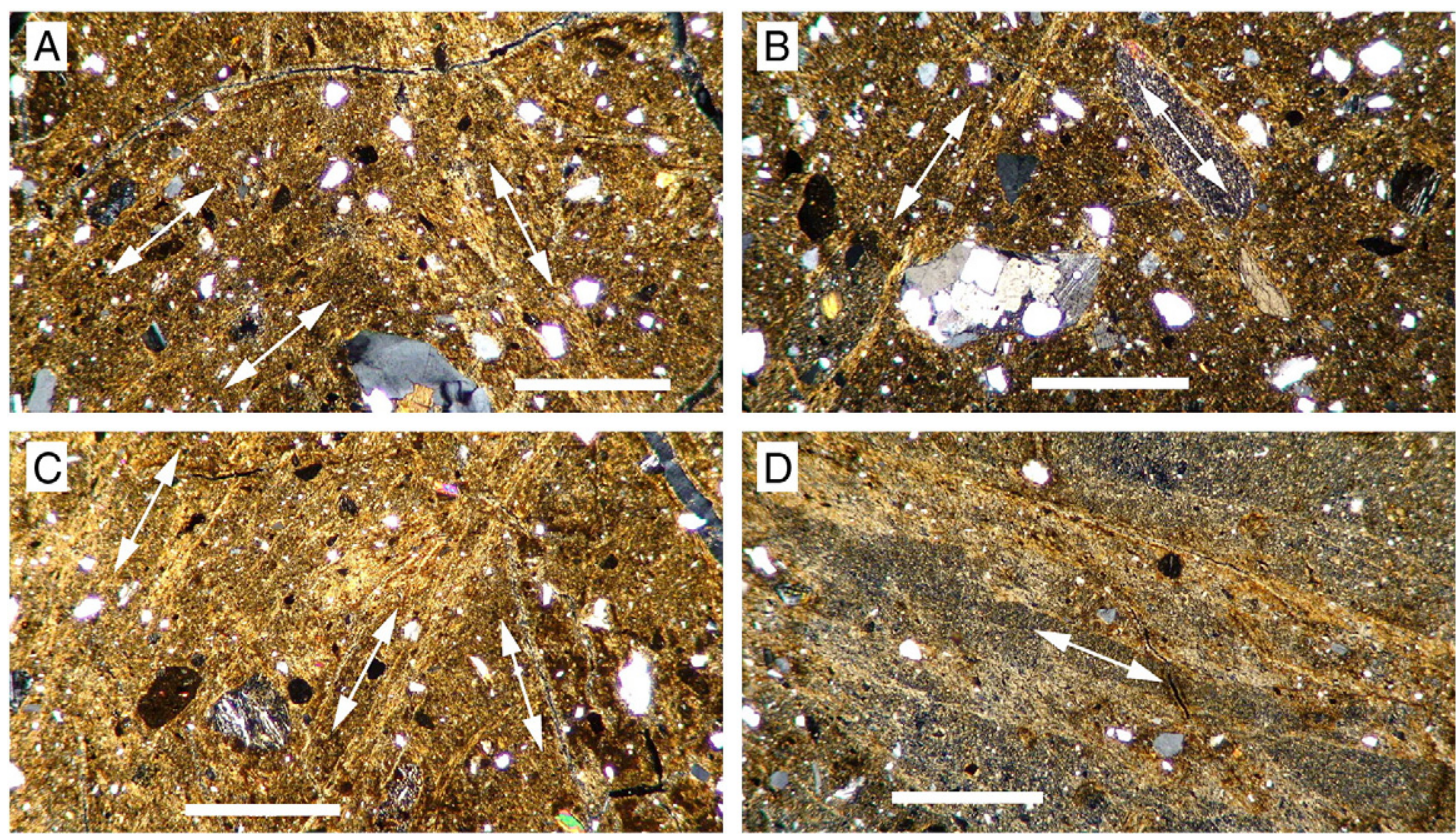

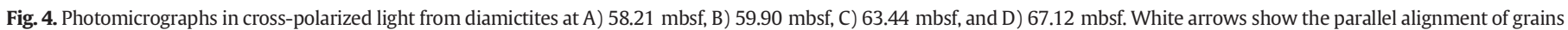
or plasma, indicating planar shearing. Scale bar $=1 \mathrm{~mm}$. 
followed by a readvance of the ice sheet (McKay et al., 2009, 2012). Macroscopically, it is unclear where the boundary occurs between subglacial and the ice shelf deposits. A bed containing granular facies is not present to mark the subglacial/ice sheet transition as in the Late Pleistocene interval or as identified from the LGM cores in the Ross Sea (Domack et al., 1999; Howat and Domack, 2003). However, TS 57.0157.08 and those below all show evidence of deformation common to subglacial sediments that have been overrun by ice (Fig. 2, Table 2). The stratified clast-rich diamictite from 57 to $59.5 \mathrm{mbsf}$ is interpreted to represent a fluctuating submarine grounding line with massive subglacial till beneath (Fig. 2). Stratification is produced as mud beds alternate with clast-rich diamictite and TS 58.21-58.28 has lineations and bimasepic plasma fabric, both providing strong evidence of shear. Increase in pore water pressure or fluctuations in thermal conditions within the till higher in the section are suggested by the presence of till pellets and fluidization in TS 57.01-57.08. The latter implies fast ice flow (Tulaczyk et al., 2001) and possibly alternation between periods when the bed experienced basal freezing and thawing near a grounding
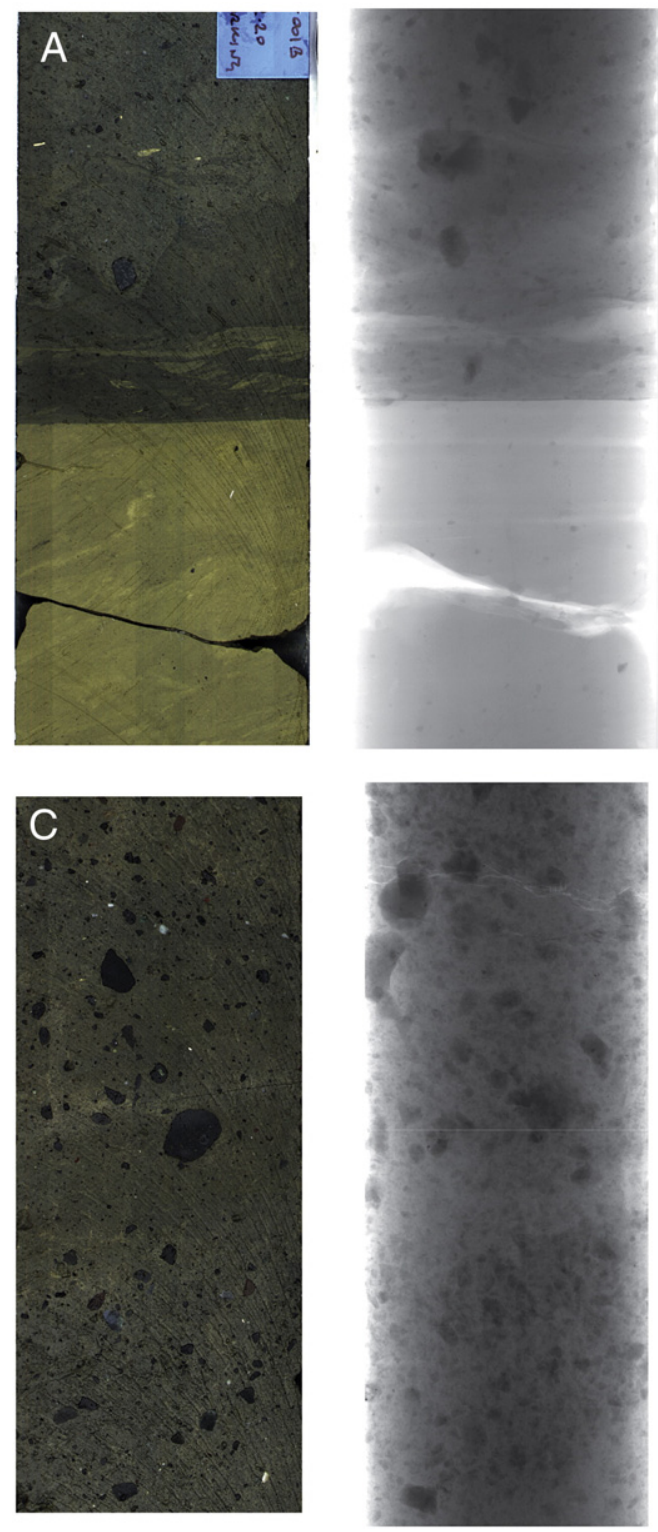

line due to an oscillating ice stream (Bougamont et al., 2011). Dynamic thinning of the ice sheet eventually caused grounding line retreat and the formation of an ice shelf at the AND-1B drill site. Clasts larger than the drill core deposited within this interval and diatom fragments support the interpretation of a grounding line nearby (Scherer et al., 2007).

\subsection{Late Pliocene ( 2.8 Ma)}

\subsubsection{Description}

The contrast in both color and density between the glacial terrigenous sediment and biogenous diatomite within the Late Pliocene interval highlights both structures and deformation on core surfaces and in $\mathrm{X}$-radiographs (Fig. 5A-D). The clearest evidence for macroscopic deformation occurs within a $0.88 \mathrm{~m}$ interval above the GSE at $211.40 \mathrm{mbsf}$ (Fig. 2). The sharp GSE occurs between the overlying mixed zone and diatomite at the base of this section (Fig. 5A). Boudins of diatomite are sheared parallel to the GSE and blocks of diamictite above are edge rounded having been modified by fluid flow. Below the GSE, diatomite
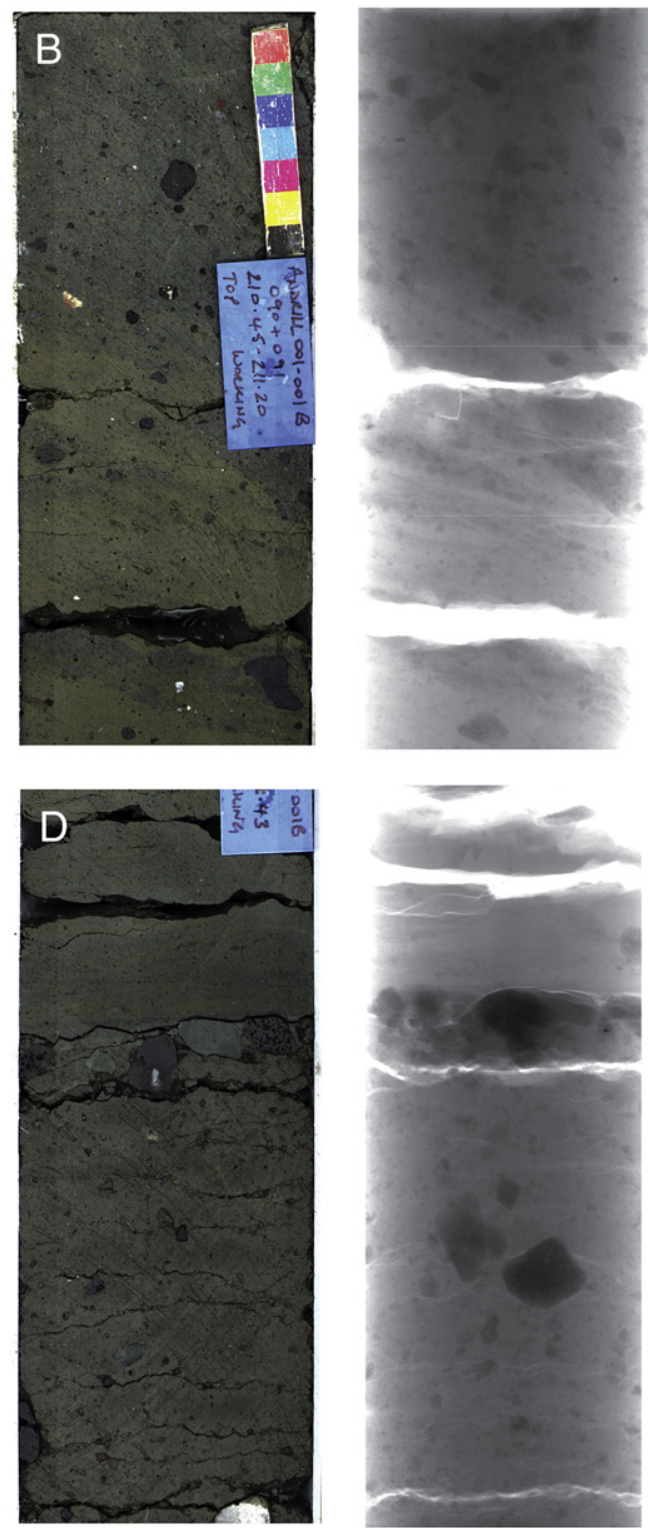

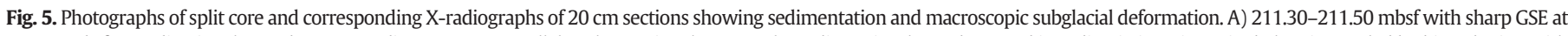

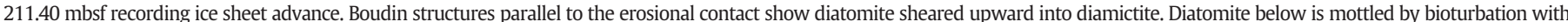

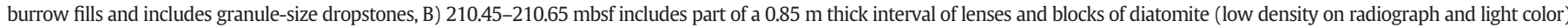

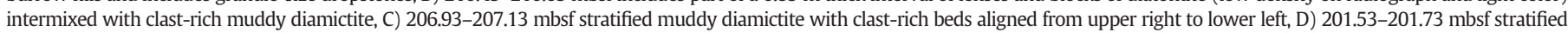
diamictite capped by a gravelly sand bed signaling a hiatus in glacimarine sedimentation with diatomite above. 


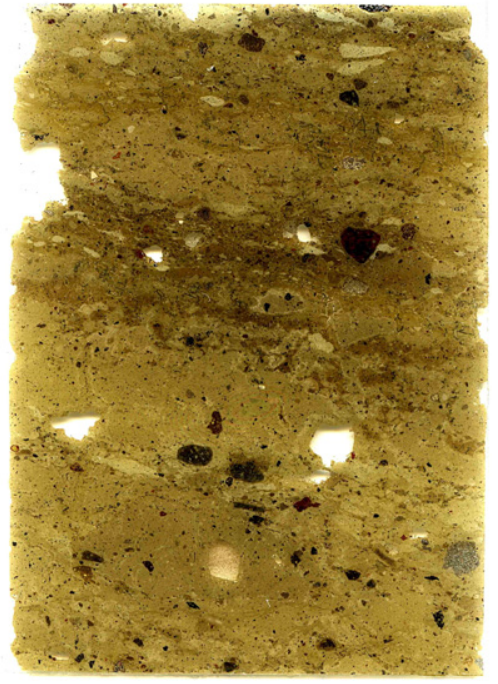

Fig. 6. Scanned thin section in plane light showing the arrangement of skeleton grains and plasma in stratified diamictite at $207.37 \mathrm{mbsf}, 45 \mathrm{~mm} \times 64 \mathrm{~mm}$. Laminae with grains and intraclasts are elongated parallel to bedding and alternate with diatomite-rich laminae.

is bioturbated and contains granule-size clasts. Shearing has intermixed diatomite and diamictite producing segregation between coarsegrained diamictite and diatomite (Fig. 5B). Within the diamictite interval, stratified muddy diamictite is clast-rich with fewer diatoms and preferred clast orientation below 205.4 mbsf (Fig. 2, Fig. 5C). The interval between 206.9 and 207.5 mbsf is interbedded diatomite-bearing muddy diamictite and sandy mudstone beds. The transition from stratified diamictite to diatomite at 201.58 mbsf is marked with angular volcanic pebbles within a sandstone bed (Fig. 5D).

Thin sections clearly show stratified diamictite formed by alternating bands of clast-rich and clast-poor diamictite (Fig. 6). The clasts and intraclasts are elongate parallel to the horizontal bedding. Intraclasts of mud appear angular at the base of the thin section and become more rounded toward the top. Within the interval interpreted as subglacial (from 206 mbsf to the lower GSE), thin sections show evidence of circular arrangement of skeletal grains and short lineations produced by alignment of grains (Fig. 7A-D). Clasts of brecciated diamictite with edge rounding are surrounded by a matrix of diatomite (Fig. 7B).

\subsubsection{Interpretation}

The Pliocene is regarded as dynamic glacial period with advance and collapse of the ice sheet recording 40 kyr periodicity (Naish et al., 2009). Glacial advance is recorded by a sharp contact between the diamictite and underlying diatomite. Thin lenses of diatomite are incorporated into the diamictite over a 1-meter thick intermixed zone above the GSE. Lower in the section, wispy laminae appear disrupted by fluid as they are smeared parallel to the erosion surface (Fig. 5A). At the top of the intermixed zone, the diatomite and clast-rich diamictite appear interstratified by shearing at a high angle across the core section. Within the clast-rich diamictite above the mixed zone, grain lineaments and turbate structures occur, indicating planar shear (Fig. 7C) and producing the macroscopic appearance of a banded till (Fig. 5B). A fluctuating grounding line is recorded in a thin stratified diamictite/diatomite interval at 207.37 mbsf (Fig. 6). Brecciation and shearing have broken up the stiff till producing intraclasts, which are then rotated producing rounding (Fig. 7B). This process is facilitated by high pore water pressure as finegrained marine sediments are incorporated into the till. Grounding line retreat occurs within the interval between TS 206.83 (Fig. 7A) and a winnowed coarse-grained lag deposit records the top of the glacial unit at 201 mbsf (Figs. 2, 5D). TS 203.18-203.26 lacks plasma orientation and contains grains with random long axis orientation. This observation along with increasing biosiliceous content suggests that this stratified diamictite was deposited in a proximal glacimarine setting where high sedimentation rates, ice conditions, or temperatures prohibited diatom blooms extensive enough to form ooze. The transition from glacial to biogenic-dominated sediment is marked by a winnowed lag deposit of sand and gravel on the sea floor (cf. Hambrey and Glasser, 2012; Figs. 2, 5D).

\subsection{Quartz sand microtextures}

All 20 samples imaged from AND-1B include grains with microtextures consistent with glacial transport. Since all quartz grains in our
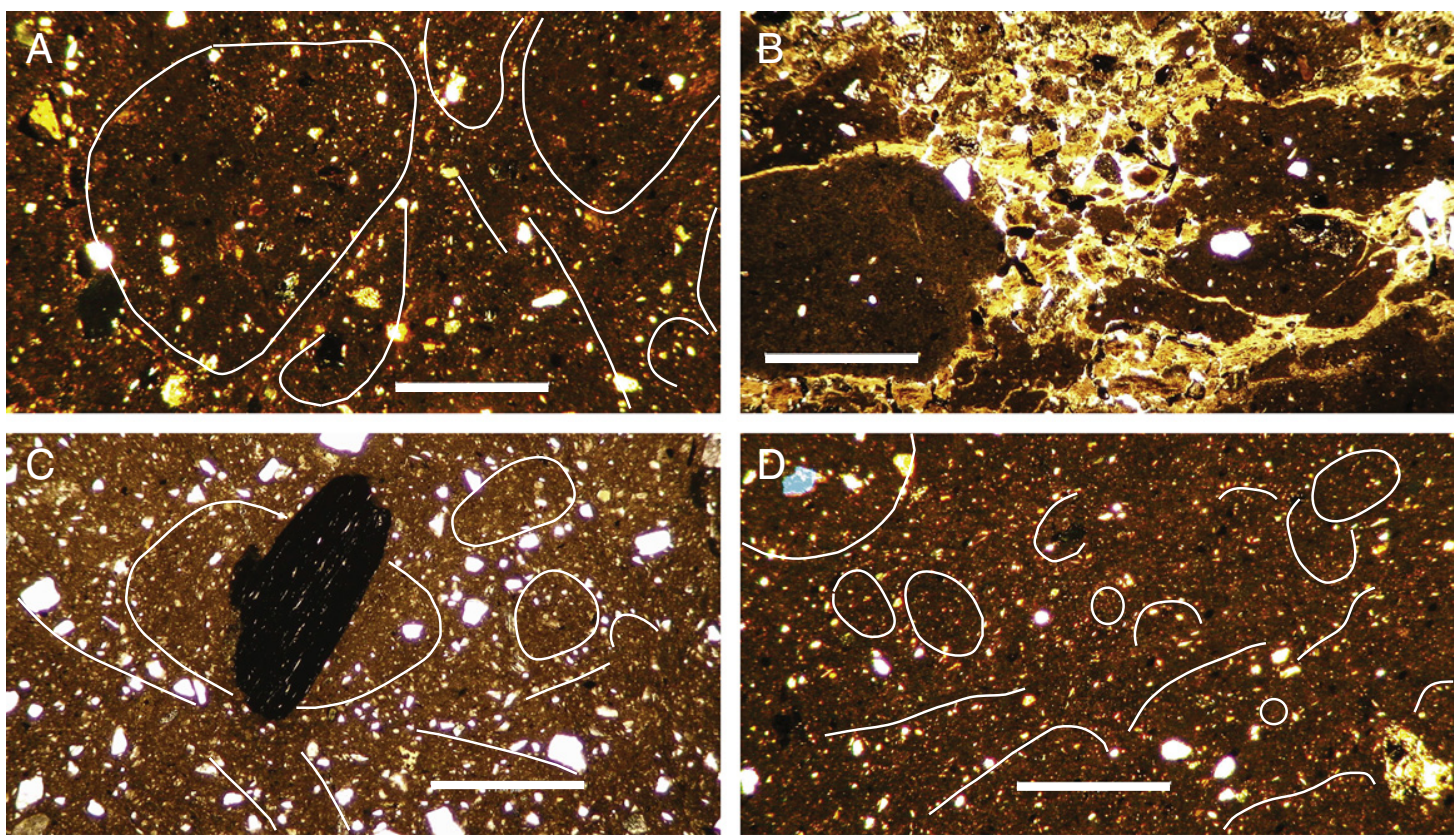

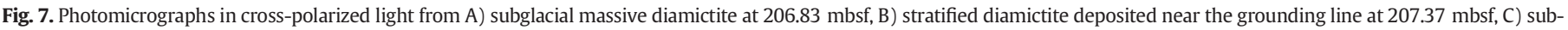

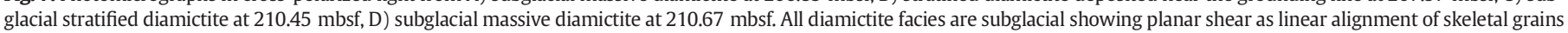
(white lines) and grain rotation (white circles). Proximity to the grounding line is inferred from diatomite intermixed with brecciated diamictite in B. Scale bar $=1 \mathrm{~mm}$ 
study originated from subglacial diamictites we used the model of grain 'styles' defined by Hart (2006) in a field study of subglacial tills in Norway to indicate the glacial regime, which is linked to the processes of ice movement (Table 3). For example, once debris is entrained at the bed it is modified by basal processes including abrasion and quarrying during intraclast collision and subglacial deformation as well as by subglacial water (Hambrey and Glasser, 2012). Hart's (2006) model proposes that grains eroded from bedrock will undergo subglacial transport that modifies them by rotation and shearing leading to microtextures dominated by abrasion (few impacts) or percussion (many impacts) or a mixture of both. In AND-1B, microtextures attributed to glacial crushing dominate in six samples (Fig. 8, Table 3). These microtextures include conchoidal fracture, arcuate and straight steps, sharp jagged features and medium to high relief grains (Mahaney, 1995, 2002; Vos et al., 2014). Microtextures attributed to abrasion or passive glacial transport such as edge rounding, low relief, smoothing or chemical etching (Van Hoesen and Orndorff, 2004) dominate in 14 of the samples (Fig. 9, Table 3). Hart (2006) postulates that grains that are rotated or sheared against smaller grains will be affected by abrasion and develop a smooth, rounded form, whereas grains that impact others will be affected by fracture and develop a conchoidal form, including a handaxe shape. The surfaces of grains from AND-1B are completely modified during transport unlike grains from the outlet glacier in Norway that retained from 7 to $31 \%$ of the preweathered surface (Hart, 2006). This may be attributed to the distance of glacial transport or remobilization and reworking of Antarctic tills over long time scales. Some grains show a history of transport that includes conchoidal fracture and later smoothing (Fig. 9A, C). There is an inverse relation between the abundance of a smooth and rounded form vs. conchoidal fracture form, which holds throughout the drill core (Table 3). In addition, smooth, rounded low-relief grains appear more abundant within samples that have a high percentage of till pellets (Table 3 ). This could result from pervasive rotation associated with the deformable bed that develops till pellets or by the shielding of sand grains from impact with others by encapsulation by skelsepic plasma.

\subsection{Clast compositions and provenance}

Clasts within the upper $250 \mathrm{~m}$ of AND-1B were counted and organized according to six major lithological groups for the core intervals with and without till pellets as previously described (Table 4). The main features of the lithological groups (intrusive and metamorphic lithologies excluded, since they will be described in more detail later in the section) are:

- Volcanic clasts include a variety of aphyric to porphyritic varieties, some vesicular and/or amygdale-bearing, ranging in composition from mafic to intermediate and felsic.

- Sedimentary clasts include at least two major lithological types: (a) quartz arenites, likely sourced from the Beacon Supergroup, and (b) intraformational clasts consisting of poorly-to moderatelysorted sandstone with granule-grade clasts (reworked diamictites including the till pellets) and gray to black mudstone and minor sandstones.

- Dolerite clasts are generally fine-or medium-grained with textural and mineralogical similarities to the Ferrar Dolerite. They display variable alteration and occur as granule to sub-rounded pebbles and cobbles.

- Quartz occurs as granules or small pebbles, some of them carrying minor micas, and are most likely fragments of coarse-grained granitoids.

The total number of clasts in each of the 46 investigated core intervals was found to range from 0 to 29 with an average value of 10 clasts; most intervals show a total clast content higher than 6 (Table 4). We cumulated the data to enable us to compare all intervals with till pellets to all of those without (Table 5). Relative proportions of clasts of intrusive rocks, quartz and volcanic rocks are nearly similar but the ratio between

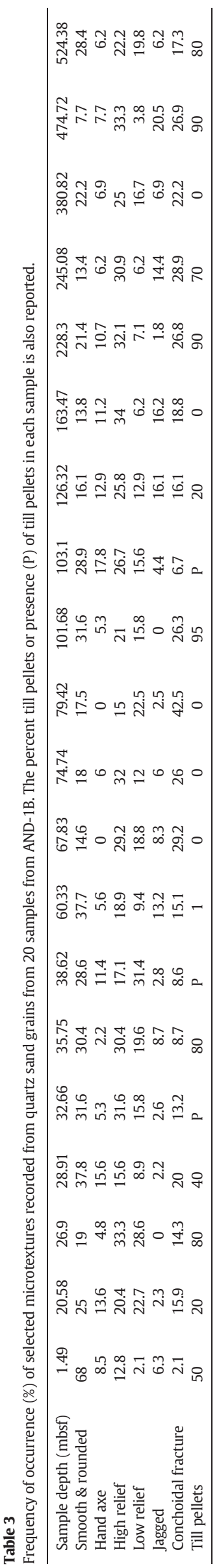



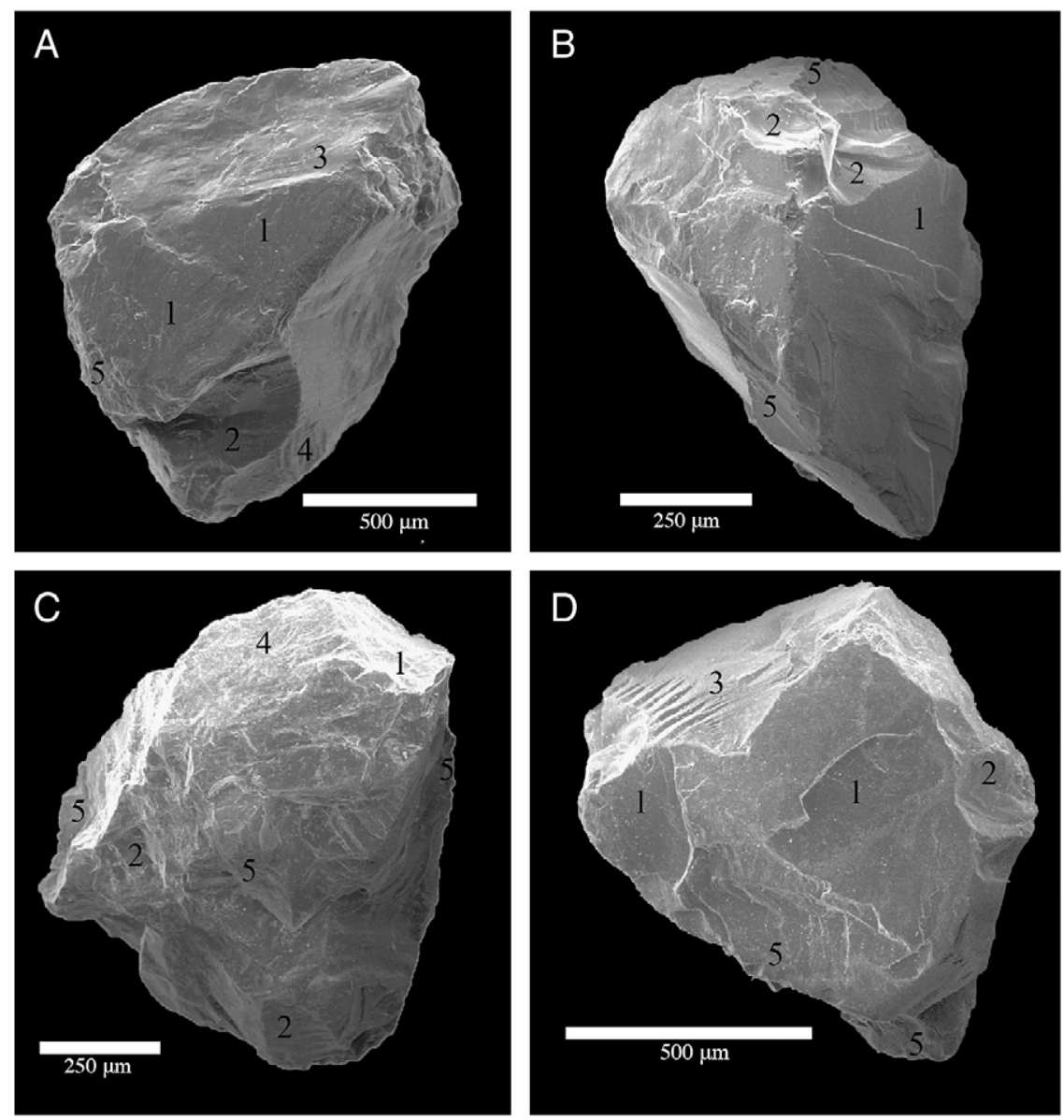

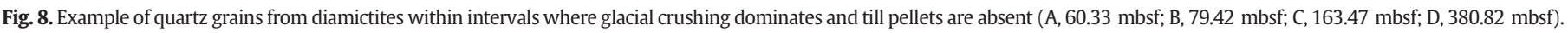

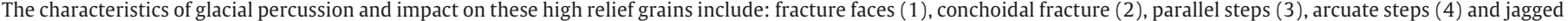
edges (5).

metamorphic and sedimentary clasts is significantly different, being high in those core sections without pellets and low in those hosting pellets. Moreover pellet-bearing intervals also include the rare occurrence of dolerite. Clasts from pellet-bearing intervals are mainly granules and small sub-angular pebbles (diameter $>2.5 \mathrm{~cm}$ ) with subordinate subangular or less commonly sub-rounded larger (3.5-4 cm diameter) pebbles. In contrast, intervals without till pellets are characterized by abundant sub-rounded clasts (estimated to equal the number of sub-angular ones) and the gravel fraction includes a slightly higher content in pebbles with diameters around $4 \mathrm{~cm}$.

In these clast assemblages, the petrographic analysis of 73 pebbles of intrusive and metamorphic rocks provides further evidence for additional lithological differences. As shown in Table 5, foliated biotite monzogranite, biotite schist and biotite paragneiss are common lithologies in core intervals with till pellets, whereas core sections without till pellets contain abundant biotite-hornblende granodiorite, biotite-calcite metasandstones, and subordinate tonalite and isotropic monzogranite.

\section{Discussion}

\subsection{Till lithofacies with and without pellets}

The upper $80 \mathrm{~m}$ of AND-1B drill core contains repeated advances of a marine ice sheet alternating with sub-ice shelf deposition in a polar climate (McKay et al., 2012). Although muddy diamictites within the two Pleistocene intervals appear macroscopically similar, there are significant differences in micromorphology, the surface textures of quartz sand grains and clast composition between them. Subglacial tills in the Late Pleistocene study interval (38-49 mbsf) are dominated by turbate structures, skelsepic plasmic fabric, till pellets and occasional fluidized zones, which is similar to micromorphology of the clay-rich and physically weak till sampled from beneath Whillans Ice Stream, WAIS (Khatwa and Tulaczyk, 2001). Quartz sand grains show edge abrasion, and are chemically etched forming smooth, rounded low-relief grains similar to those identified beneath the Whillans Ice Stream where little evidence of grain crushing was observed (Tulaczyk et al., 1998). During transport, grains were less likely to be impacted by percussion because they were protected from contact with other grains by the surrounding clays during rotation or enclosed within a till pellet. Subglacial sediment deformation was likely to be concentrated in a zone measuring just a few $\mathrm{cm}$ from the ice base, as observed beneath Whillans Ice Stream (Engelhardt and Kamb, 1998). Whereas material encapsulated in this narrow shear zone would be exposed to high gradients of shear and thus grain rotation, sediment deposition should counteract this effect by protecting the deeper sedimentary units from grain crushing and shear deformation in general. The lithofacies association and micromorphology of till in the Late Pleistocene interval is consistent with that described from the LGM ice streams in the Ross Sea including the presence of a pellet-rich granulated bed marking the transition from subglacial till to ice shelf deposits (cf. Domack et al., 1999). Ice streams are interpreted to override and recycle preexisting poorly indurated sediments moving as a deformable bed. The presence of ductile deformation indicates high pore water pressure (Piotrowski et al., 2006). The frequency of till pellets (also termed polymicts) in LGM sediment cores 

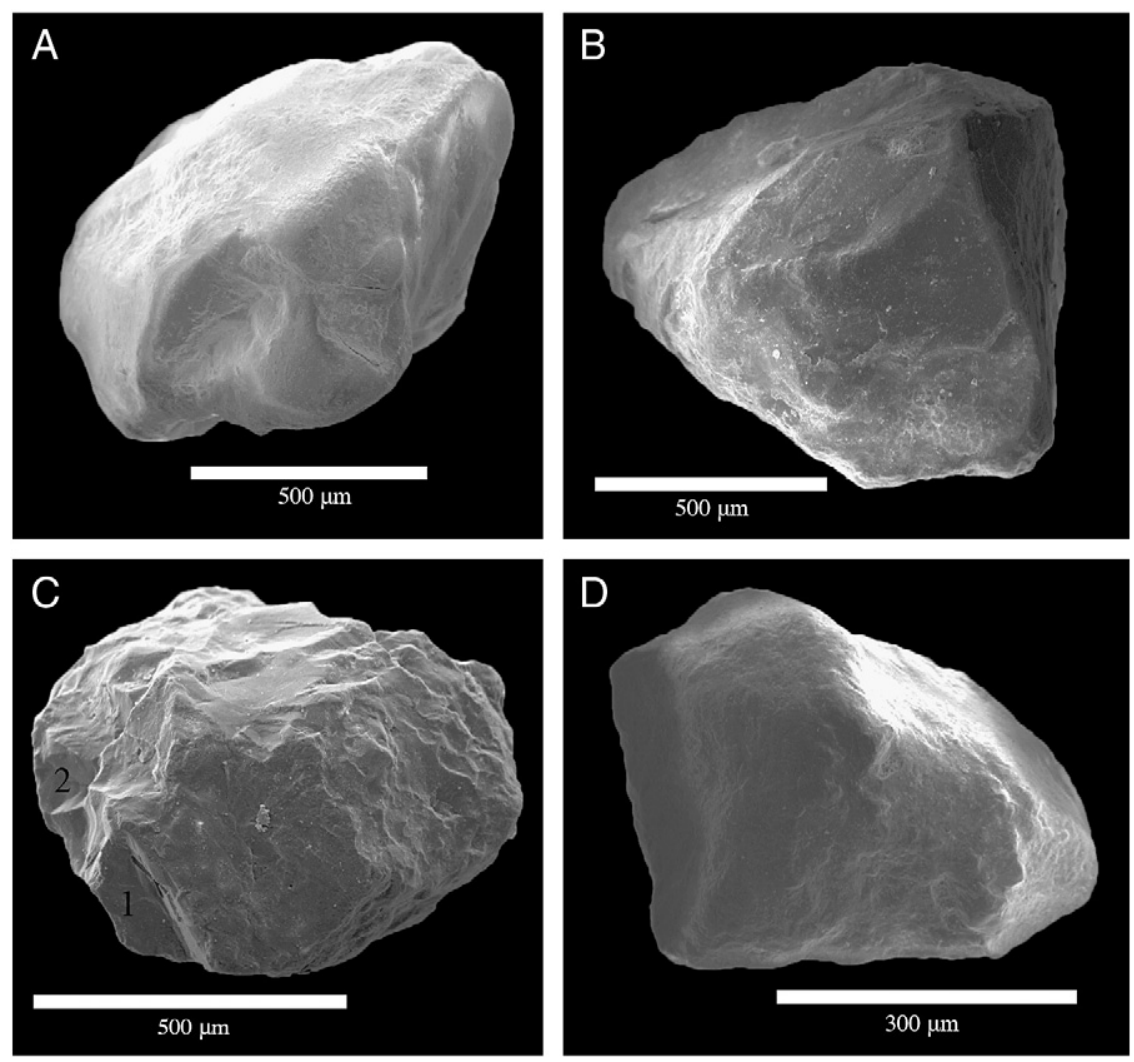

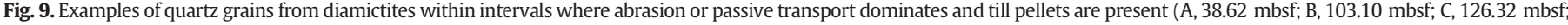

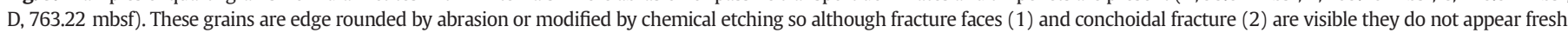

has been used to infer ice stream behavior and the presence of water at the bed across the Ross Sea (Weiler and Licht, 2011). Licht and Palmer (2013) identified abundant (up to 90\%) polymict grains similar to till pellets in LGM cores from the western Ross Sea. They also found large quantities (45-58\%) in three modern moraines at Byrd Glacier, a large and fast flowing outlet of the East Antarctic Ice Sheet, which drains 1.1 million $\mathrm{km}^{2}$ (Licht and Palmer, 2013) and has a polythermal bed (Sterns, 2011) similar to those of the Ross ice streams (Joughin et al., 2004). Although bedrock of the Byrd Glacier region contributes to Provenance area $A$ of this study, we do not consider that till pellets from that area contributed to AND-1B. As we have no samples from the Byrd area we cannot be certain, however our observations suggest that AND-1B till pellets are a signature of a particular deforming bed regime formed closer to their depositional location. Of the seven moraines sampled at Byrd Glacier, only three with $20 \%$ or more clay contained polymict grains (Licht and Palmer, 2013). This reinforces the observation that a high clay content of the bed is a prerequisite for grain rotation and development of skelsepic plasmic fabric (van der Meer et al., 2003) necessary for till pellet formation.

In contrast to the Late Pleistocene, Mid-Pleistocene diamictites (between 58 and $68 \mathrm{mbsf}$ ) are dominated by pervasive linear shear zones with no evidence of rotation or till pellets, even though the clay content is as high as in the Late Pleistocene diamictites. At the SEM scale, the quartz grains are dominated by evidence for percussion and glacial comminution, producing conchoidal fracture, fracture facies and jagged edges on high relief grains (Table 3; Hart, 2006). The high frequency of these glacial microtextures is suggested to result from grain breakage during transport in a high-traction subglacial environment where the effective stress associated with pressure between individual grains was high, and ice flow therefore likely to be slow. Kjær (1999) found that a transport distance of only $250 \mathrm{~m}$ was enough for subglacial till to develop a mature state with respect to comminution processes. Therefore, brittle deformation structures and quartz grain microtextures are likely both related to conditions at the ice sheet bed (Menzies et al., 2010) rather than distance from bedrock source or the number of times the subglacial sediment has been recycled. More frequent grain collisions, brittle deformation and an increase in intergranular friction have been associated with low pore water pressure in many tills (van der Meer, 1997; Larsen et al., 2006; Piotrowski et al., 2006). An increase in pore water pressure is however, postulated near the GSE at the top of the section where till pellets and turbate structures occur (Table 2). These deposits are associated with advance of the ice sheet into the Ross Sea (Fig. 2) with thicker ice introducing warmer and wetter basal conditions at the AND-1B site. In this interval the transition from subglacial sediment to interglacial ice shelf is not marked by a definitive transition and appears gradational.

In the Late Pliocene, glaciers advanced as tidewater cliffs into a warmer Ross Sea than during Pleistocene (McKay et al., 2009; Naish et al., 2009). The sharp planar contact of the GSE and minor deformation associated with it suggests that the ice sheet advanced on a waterlubricated surface of saturated diatomite, with water pressure effectively decoupling the glacier from its bed as it advanced across the sea floor (i.e. Phillips et al., 2007). Diamictites in the interval from 201 to 212 mbsf record ductile deformation in the form of a few turbate structures but contain no evidence of till pellets, possibly because the ice sheet consisted of polythermal rather than cold polar ice. The proximity to the fluctuating grounding line and hydrofracturing by high pore water pressure is indicated by the brecciation and rounding of diamictite clasts (Fig. 7B). Although thinner than Pleistocene, the Late Pliocene ice sheet could have been wet at its bed because of warmer temperatures globally. The Late Pliocene setting may resemble that of presentday Greenland, where fast-flowing outlet glaciers terminate in fjords containing relatively warm water (Holland et al., 2008) and where large volumes of surface meltwater enter the subglacial environment via moulins and crevasses, causing large seasonal variation in ice flow (Bartholomew et al., 2010). The transition from ice proximal to open 
Table 4

Clast compositions in investigated core intervals $10 \mathrm{~cm}$ thick centered on specific depths with and without till pellets as described in Cowan et al. (2012) in the uppermost $250 \mathrm{~m}$ of AND-1B core. Shading emphasizes intervals that contain till pellets. Volc = volcanic clasts; Intrus = intrusive rocks; Sed = sedimentary clasts; Metam = metamorphic clasts; $\mathrm{Otz}=$ quartz; Doler $=$ dolerite; $\mathrm{Sa}=$ sub-angular; $\mathrm{Sr}=$ sub-rounded. Till pellet

\begin{tabular}{|c|c|c|c|c|c|c|c|c|c|}
\hline \multirow[t]{2}{*}{ Depth (mbsf) } & \multirow[t]{2}{*}{$\begin{array}{l}\text { Till pellet } \\
\text { occurrence }\end{array}$} & \multicolumn{7}{|c|}{ Clast compositions ( $10 \mathrm{~cm}$ interval) } & \multirow[b]{2}{*}{$\begin{array}{l}\text { Clast } \\
\text { dimension } \\
\text { and shape }\end{array}$} \\
\hline & & Volc & Intrus & Sed & Metam & Qtz & Doler & Tot & \\
\hline 0.21 & 0 & 3 & & & & & & 3 & $<1.2 \mathrm{~cm}, \mathrm{sr}>\mathrm{sa}$ \\
\hline 1.49 & 50 & 1 & & & 1 & & & 2 & $<2 \mathrm{~cm}, \mathrm{sr}$ \\
\hline 20.58 & 20 & & & & & & & 0 & \\
\hline 26.68 & $\mathrm{P}$ & 2 & & 7 & & & & 9 & $<1 \mathrm{~cm}, \mathrm{sr}>\mathrm{sa}$ \\
\hline 26.90 & 80 & 1 & & 3 & & & & 4 & $<2 \mathrm{~cm}, \mathrm{sr}>\mathrm{sa}$ \\
\hline 28.89 & $\mathrm{P}$ & 7 & & 3 & & 1 & & 11 & $<1 \mathrm{~cm}, \mathrm{sa}>\mathrm{sr}$ \\
\hline 28.91 & 40 & 7 & & 3 & & 1 & & 11 & $<1 \mathrm{~cm}, \mathrm{sa}>\mathrm{sr}$ \\
\hline 31.16 & $\mathrm{P}$ & 13 & 1 & 1 & & 2 & & 17 & $<2.5 \mathrm{~cm}, \mathrm{sa}>\mathrm{sr}$ \\
\hline 35.76 & 80 & 6 & 1 & & & 1 & & 8 & $<3.5 \mathrm{~cm}, \mathrm{sa}>\mathrm{sr}$ \\
\hline 35.82 & $\mathrm{P}$ & 12 & & & 1 & 1 & & 14 & $<3.5 \mathrm{~cm}, \mathrm{sa}>\mathrm{sr}$ \\
\hline 38.72 & 20 & 4 & & & & & 1 & 5 & $<3.5 \mathrm{~cm}, \mathrm{sa}>\mathrm{sr}$ \\
\hline 38.78 & $\mathrm{P}$ & 3 & 1 & & & & & 4 & $<3.5 \mathrm{~cm}, \mathrm{sa}>\mathrm{sr}$ \\
\hline 41.63 & $\mathrm{P}$ & 5 & & 3 & & & 1 & 9 & $<4 \mathrm{~cm}, \mathrm{sr}>\mathrm{sa}$ \\
\hline 43.94 & $\mathrm{P}$ & 2 & 1 & 6 & 1 & & & 10 & $<1 \mathrm{~cm}, \mathrm{sa}>\mathrm{sr}$ \\
\hline 46.25 & P & 3 & & 8 & 1 & & & 12 & $<0.5 \mathrm{~cm}$ \\
\hline 47.66 & $\mathrm{P}$ & 2 & 2 & 2 & 2 & & & 8 & $<1.5 \mathrm{~cm}, \mathrm{sa}>\mathrm{sr}$ \\
\hline 48.03 & $\mathrm{P}$ & 3 & 3 & & & 3 & & 9 & $<10 \mathrm{~cm}, \mathrm{sr}>\mathrm{sa}$ \\
\hline 48.83 & P & 6 & & 2 & & 2 & & 10 & $<0.5 \mathrm{~cm}$ \\
\hline 55.97 & $\mathrm{P}$ & 2 & 1 & 4 & 3 & & & 10 & $<1.5 \mathrm{~cm}, \mathrm{sa}>\mathrm{sr}$ \\
\hline 56.40 & $\mathrm{P}$ & 5 & & 4 & & & & 9 & $<0.4 \mathrm{~cm}$ \\
\hline 57.01 & A & 8 & 2 & 6 & & 1 & & 17 & $<2 \mathrm{~cm}, \mathrm{sr}>\mathrm{sa}$ \\
\hline 58.21 & A & 3 & 1 & & 2 & 1 & & 7 & $<2 \mathrm{~cm}, \mathrm{sr}>\mathrm{sa}$ \\
\hline 59.90 & A & 3 & 2 & 1 & 2 & & & 8 & $<4 \mathrm{~cm}, \mathrm{sr}>\mathrm{sa}$ \\
\hline 60.33 & 1 & 5 & 1 & 1 & & 1 & 2 & 10 & $<2.5 \mathrm{~cm}, \mathrm{sa}>\mathrm{sr}$ \\
\hline 63.44 & A & 3 & 1 & 1 & & & & 5 & $<4 \mathrm{~cm}, \mathrm{sa}>\mathrm{sr}$ \\
\hline 66.59 & A & 5 & 3 & & & 1 & & 9 & $<1 \mathrm{~cm}, \mathrm{sr}>\mathrm{sa}$ \\
\hline 67.12 & A & 1 & 4 & 1 & 1 & 2 & & 9 & $<0.5 \mathrm{~cm}$ \\
\hline 70.75 & A & & & 3 & 3 & & & 6 & $<2.5 \mathrm{~cm}, \mathrm{sa}>\mathrm{sr}$ \\
\hline 74.71 & A & 2 & & 2 & & 2 & & 6 & $<4 \mathrm{~cm}, \mathrm{sa}>\mathrm{sr}$ \\
\hline 74.74 & 0 & 3 & & 1 & & 2 & & 6 & $<4 \mathrm{~cm}, \mathrm{sa}>\mathrm{sr}$ \\
\hline 79.42 & 0 & & 1 & & & 1 & & 2 & $<1 \mathrm{~cm}, \mathrm{sr}>\mathrm{sa}$ \\
\hline 101.68 & 95 & 6 & & & 2 & & & 8 & $<2.5 \mathrm{~cm}, \mathrm{sa}>\mathrm{sr}$ \\
\hline 126.32 & 20 & 4 & 2 & & 3 & 4 & & 13 & $<2.5 \mathrm{~cm}, \mathrm{sa}>\mathrm{sr}$ \\
\hline 148.30 & A & 18 & & 3 & 5 & & & 26 & $<1 \mathrm{~cm}, \mathrm{sa}>\mathrm{sr}$ \\
\hline 150.42 & A & 2 & 1 & 1 & 13 & 1 & & 18 & $<2.5 \mathrm{~cm}, \mathrm{sa}>\mathrm{sr}$ \\
\hline 181.94 & A & & 2 & & 25 & 2 & & 29 & $<4 \mathrm{~cm}, \mathrm{sr}>\mathrm{sa}$ \\
\hline 191.24 & A & 10 & & 2 & & & & 12 & $<0.5 \mathrm{~cm}$ \\
\hline 203.18 & A & 9 & & & & & & 9 & $<0.5 \mathrm{~cm}$ \\
\hline 206.83 & A & 19 & 1 & & & & & 20 & $<2.5 \mathrm{~cm}, \mathrm{sr}>\mathrm{sa}$ \\
\hline 207.37 & A & 19 & & & & & & 19 & $<0.4 \mathrm{~cm}$ \\
\hline 208.69 & 0 & 6 & 1 & & 11 & & & 18 & $<2.5 \mathrm{~cm}, \mathrm{sr}>\mathrm{sa}$ \\
\hline 210.45 & A & 5 & & & 5 & & & 10 & $<1 \mathrm{~cm}, \mathrm{sa}>\mathrm{sr}$ \\
\hline 210.67 & A & 6 & 1 & & 1 & & & 8 & $<1 \mathrm{~cm}, \mathrm{sa}>\mathrm{sr}$ \\
\hline 225.38 & $P$ & 6 & & & 1 & & & 7 & $<0.4 \mathrm{~cm}$ \\
\hline 228.30 & 90 & 4 & & & & & & 4 & $<0.5 \mathrm{~cm}$, sa \\
\hline 245.08 & 70 & 8 & & & & 1 & & 9 & $<0.4 \mathrm{~cm}$ \\
\hline \multicolumn{10}{|c|}{ Relative proportions of lithologies (\%) } \\
\hline & & Volc & Intrus & Sed & Metam & Qtz & Doler & & Metam/Sed+Metam ratio \\
\hline Intervals v & till pellets & 55 & 6 & 22 & 7 & 8 & 2 & & 0.24 \\
\hline Intervals witho & out till pellets & 51 & 8 & 8 & 27 & 5 & 0 & & 0.77 \\
\hline
\end{tabular}

marine conditions is recorded by a winnowed lag deposit on the sea floor prior to the start of diatomite deposition.

\subsection{Provenance of tills}

Core intervals with till pellets show basement clast assemblages which are significantly less varied in terms of the lithological types with respect to core intervals that lack till pellets (Table 5). Although some lithologies occur in both pellet-free and pellet-bearing intervals, these are generally represented by only a few clasts, whereas some of the rock types forming the most common occurrences are only in pellet-bearing intervals (i.e., foliated monzogranite, biotite paragneiss, schists) and yet some others are ubiquitous only in core intervals without till pellets (i.e., granodiorite, isotropic monzogranite, tonalite, metasandstone, phyllite, granofels). As shown in Table 5, all main lithologies and the rock types occurring as a few clasts can be attributed to distinctive rock units/source areas, which are located in the region between the Byrd and Skelton Glaciers in South Victoria Land (Fig. 1). These provenance inferences are based on the petrographic comparison of investigated clasts with bedrock samples and the literature for all the main basement rock units of the Ross Orogen in South Victoria Land. The results agree with provenance models previously proposed by Talarico et al. (2010) and Talarico and Sandroni (2009). Variability in clast composition between intervals with till pellets and those without indicates that ice flowed to the core site from two very distinct regions in the TAM and that the associated subglacial conditions and processes were very different. We specifically find that transport and depositional processes operated in distinct glacial regimes, which can be summarized as follows:

- Diamictite with till pellets: Provenance area A is sourced from the Britannia Range, between Byrd and Darwin Glaciers (Fig. 1). In that area, there are similar proportions of medium-grade metamorphic and intrusive basement rocks. Beacon Supergroup and Ferrar Dolerite are both extensively exposed in both Byrd and Darwin Glacier drainage basins. In the core intervals studied, minor rounded basement clasts may have originated by reworked glacimarine sediments originally deposited by ice-proximal rainout during a previous interglacial, as interpreted by Cowan et al. (2012) for the Late Pleistocene at $47.7 \mathrm{mbsf}$. The large number of sub-angular clasts suggests that subglacial processes did not completely modify the shape during subglacial transport.

- Diamictite without till pellets: Provenance area B is sourced from the region that encompasses the area between the Darwin and Skelton Glaciers (Fig. 1). Lithologies within this area support the observed dominance of low-grade metamorphic clasts in the assemblages, because extensive outcrops of phyllites and metasandstones volumetrically prevail over intrusive rocks between Teall Island and Skelton Glacier. Flow lines must have originated in drainage systems of Carlyon, Mulock and Skelton Glaciers. The large number of subrounded clasts and larger pebbles suggests more extensive reworking of ice-rafted debris available from previous interglacial periods.

\subsection{Sedimentological response to growth of WAIS}

Although the AND-1B core contains diamictites with two different provenance areas in the TAM, previous studies have shown that TAM outlet glaciers do not contribute enough ice to support the marinebased ice sheet and ice shelves in the Ross Sea that existed during glacial periods in the Plio-Pleistocene (Pollard and DeConto, 2009). Additional ice must also be supplied from ice streams originating from West Antarctica (Fig. 1). With a larger contribution from WAIS, glacial flow lines are shifted to the west introducing Provenance area A (Byrd Glacier) to the drill site. Therefore, provenance changes recorded in the subglacial load of the ice sheet overriding the AND-1B drill site directly reflect source area changes from southern-TAM outlet glaciers and indirectly reflects the size of the WAIS. Furthermore, the transition in flow from local TAM outlet glaciers to the further traveled Provenance area A was accompanied by a distinct change in subglacial conditions. In the Late Pliocene, the ice sheet transporting clasts from Provenance area B was associated with a water-lubricated subglacial environment similar to that found in Greenland today, with fast flowing glaciers advancing over high-traction beds. The glaciers were likely slower during the Mid-Pleistocene when a cold climate caused a cold ice sheet to advance relatively slowly over the drill site. The Late Pleistocene was associated with high water pressure in tills located beneath the relatively thick ice of an ice sheet extending farther into the Ross Sea compared to the Mid-Pleistocene, a lower-traction bed and conditions similar to those observed beneath modern ice streams in WAIS today.

Late Pleistocene diamictites in AND-1B are characteristic of a deformable bed with high pore-water pressure and a lack of comminution that is typical of modern ice streams (Tulaczyk et al., 1998). Mid-Pleistocene diamictites have experienced brittle deformation, indicating low subglacial water pressure in a high-traction glacier bed over which ice would move slowly by internal deformation and without basal sliding. The onset of fast ice streaming motion reflected in deposits above $56 \mathrm{mbsf}$ in the core is not related to bathymetric changes or changes in the physical nature of the bed because the drill site sits in a basin with a water depth of $\sim 935 \mathrm{~m}$ and had soft sediment substrate since the Miocene (Naish et al., 2009; McKay et al., 2012). Rather, the sedimentary signature of ice streaming suggests a paleoclimatic shift that resulted in a thicker, faster and more extended WAIS causing a westward shift in 


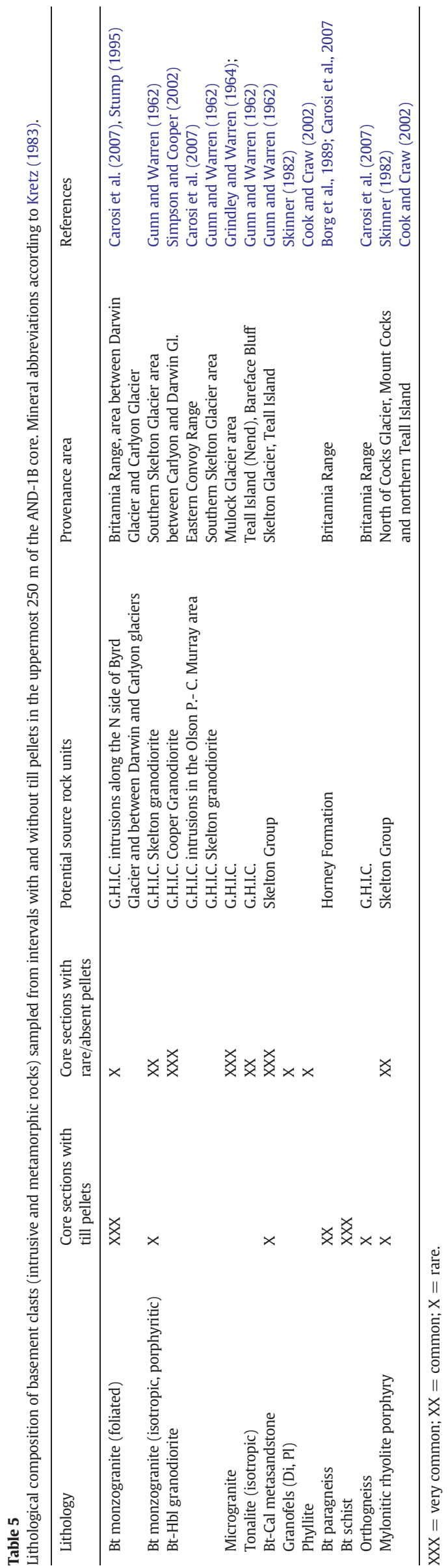

glacial flow lines of the TAM outlet glaciers and thereby introducing Byrd Glacier provenance (area A) to the drill site (Fig. 1). Ice thickness is suggested to govern pore water pressure at the bed because other intrinsic variables, including till grain size remains unchanged.

We have previously concluded that till-pellet facies is characteristic of the deformable bed of paleo-ice streams in the Ross Sea (Cowan et al., 2012). Here we link till pellets to other characteristics of the deforming bed and to a change in the provenance signature of till deposited by glaciers in the TAM over the last 2.8 million years. The absence of till pellets in the Late Pliocene sequence of the AND-1B core may be related to relatively warm environmental conditions resembling that of the modern Greenland Ice Sheet, where fast flow is induced when glaciers terminate in open water and by drainage of surface meltwater to the bed (Das et al., 2008; Hoffman et al, 2011). This indicates that a bed overlain by relatively cold ice may be needed to form till pellets which suggests that the thermal model of formation may be more likely than the mechanical alternative (Cowan et al., 2012).

Although till pellets do not occur within the Late Pliocene interval evaluated in this paper, we note that they are abundant in diamictites within selected intervals of the AND-1B drill core within the lower Pliocene and Miocene (Cowan et al., 2012) suggesting that paleo-ice streams formed during some periods in the earlier history of Antarctic glaciation. The reason for this may lie in the ability of fast flowing ice steams to advect cold ice from interior to coast, resulting in polythermal conditions similar to Jakobshavn Isbræ presently the largest and fastest-flowing glacier in Greenland and which contains cold ice $\left(-22{ }^{\circ} \mathrm{C}\right)$ despite much warmer conditions on the surface and at the bed (Iken et al., 1993). The notion of ice streams being present earlier in the Antarctic Ice Sheet history supports observations by Smellie et al. (2013) that ice flow with evolving basal regimes and variable deformation of the substrate was present throughout the region since 12 Ma rather than evidence of a unidirectional step-change to frozen bed conditions at the Middle Miocene Climatic Transition (Lewis et al., 2007). In prior studies of AND-1B drill core, Pliocene age interglacial facies were interpreted as temperate water diatomites (McKay et al., 2009, 2012). Here we show how analysis of subglacial diamictites can be used to constrain glacial dynamics, thus demonstrating that not only were the Pliocene interglacials warmer than the Pleistocene and at present, but that the glacials were also warmer. Therefore, we consider that the extreme cold glacial conditions in the Ross Sea commenced in the Pleistocene, likely after the Mid-Pleistocene Transition, 0.8 Ma ago, as has been suggested by Naish et al. (2009).

\section{Conclusions}

- Investigations of lithofacies associations, micromorphology, and quartz sand grain microtextures of muddy diamictites within selected intervals of the AND-1B core allow differentiation of fast-flowing paleo-ice streams from local slower moving inland ice.

- Ice streams are characterized by ductile deformation with high porewater pressure resulting in pervasive rotation and formation of till pellets and low-relief and rounded sand grains dominated by abrasion, whereas inland ice records brittle deformation producing lineations and bi-masepic and unistrial plasma fabric, along with highrelief, conchoidally fractured quartz grains.

- The absence of till pellets in the Late Pliocene till may result from relatively warm environmental conditions at this point in time relative to present, suggesting that their formation may require polythermal conditions at the bed stemming from a cold polar environment.

- Changes in the provenance of gravel to cobble-size clasts support a provenance source area of Byrd Glacier (Provenance area A) for fast flowing paleo-ice streams and an area between Darwin and Skelton Glaciers (Provenance area B) for slow inland ice flow.

- The provenance change in tills stems from shift in glacial flow lines at the core site, which indirectly reflects changes in the size and thickness of WAIS and may therefore be a proxy for the state and variability of Antarctic glaciation. 
- The various regimes of ice flow recorded in the upper $212 \mathrm{~m}$ of the AND-1B core span from one that resembles the modern Greenland Ice Sheet, where fast flow is induced by drainage of surface meltwater to the bed and where glaciers terminate directly in the sea (201212 mbsf) to polar conditions which are similar to modern ice streams in WAIS (38-49 mbsf). The presence of till pellets only in the deposits from the latter type of fast flow demonstrates how micromorphology can provide important data on paleoglacial processes and conditions.

- Studies of till pellets so far indicate that their formation requires a fine-grained bed (clay content $>20 \%$ ) with high pore-water pressure and low traction, resulting in fast ice streaming motion and ice temperature distributions similar to those observed in WAIS and Greenland today.

\section{Acknowledgments}

The ANDRILL project is a multinational collaboration among the Antarctic programs of Germany, Italy, New Zealand, and the United States. Scientific studies are jointly supported by the U.S. National Science Foundation, the New Zealand Foundation for Research, the Royal Society of New Zealand Marsden Fund, the Italian Antarctic Research Program, the German Science Foundation, and the Alfred-Wegener Institute for Polar and Marine Research. We wish to acknowledge the contributions of the on-ice MIS core description team, as well as Matt Ake, who collected the SEM photomicrographs at Appalachian State University. We appreciate the comments of two anonymous reviewers.

\section{References}

Alley, R.B., Blankenship, D.D., Bentley, C.R., Rooney, S.T., 1986. Deformation of till beneath ice stream B, West Antarctica. Nature 322, 57-59.

Alley, R.B., Blankenship, D.D., Rooney, S.T., Bentley, C.R., 1989. Sedimentation beneath ice shelves - the view from ice stream B. Mar. Geol. 85, 101-120.

Bartholomew, I., Nienow, P., Mair, D., Hubbard, A., King, M.A., Sole, A., 2010. Seasonal evolution of subglacial drainage and acceleration in a Greenland outlet glacier. Nat. Geosci. 3, 408-411.

Borg, S.G., DePaolo, D.J., Wendlandt, E.D., Drake, T.G., 1989. Studies of granites and metamorphic rocks, Byrd Glacier area. Antarct. J. US 24, 19-21.

Bougamont, M., Price, S., Christoffersen, P., Payne, A.J., 2011. Dynamic patterns of ice stream flow in a 3-D higher order ice sheet model with plastic bed and simplified hydrology. J. Geophys. Res. Earth Surf. 116, 13.

Carosi, R., Giacomini, F., Talarico, F., Stump, E., 2007. Geology of the Byrd Glacier discontinuity (Ross Orogen): new survey data from the Britannia Range, Antarctica. In: Cooper, A.K., Raymond, C.R., Stagg, H., Storey, B., Stump, E., Wise, W. (Eds.) Antarctica: A Keystone in a Changing World, Online Proceedings of the 10th ISAES, USGS Open-File Report 2007-1047, Short Research Paper 030. http://dx.doi.org/10. 3133/of2007-1047.srp030 (6 pp.).

Carr, S.J., 2001. Micromorphological criteria for discriminating subglacial and glacimarine sediments: evidence from a contemporary tidewater glacier, Spitsbergen. Quat. Int $86,71-79$.

Carr, S.J., Haflidason, H., Sejrup, H.P., 2000. Micromorphological evidence supporting Late Weichselian glaciation of the Northern North Sea. Boreas 29, 315-328.

Christoffersen, P., Tulaczyk, S., Behar, A., 2010. Basal ice sequences in Antarctic ice stream: exposure of past hydrologic conditions and a principal mode of sediment transfer. J. Geophys. Res. 115, F03034. http://dx.doi.org/10.1029/2009JF001430.

Cook, Y.A., Craw, D., 2002. Neoproterozoic structural slices in the Ross Orogen, Skelton Glacier area, South Victoria Land, Antarctica. N. Z. J. Geol. Geophys. 45, 133-143.

Cowan, E.A., Hillenbrand, C.D., Hassler, L.E., Ake, M.T., 2008. Coarse-grained terrigenous sediment deposition on continental rise drifts: a record of Plio-Pleistocene glaciation on the Antarctic Peninsula. Palaeogeogr. Palaeoclimatol. Palaeoecol. 265, 275-291.

Cowan, E.A., Christoffersen, P., Powell, R.D., 2012. Sedimentological signature of a deformable bed preserved beneath an ice stream in a Late Pleistocene glacial sequence, Ross Sea, Antarctica. J. Sediment. Res. 82, 270-282.

Craddock, C., 1970. Tectonic map of Gondwana, in geologic maps of Antarctica. In: Bushnell, V.C., Craddock, C. (Eds.), Antarctic Map Folio Series, Folio 12, Plate XXIII. American Geographical Society, New York.

Das, S.B., Joughin, I., Behn, M.D., Howat, I.M., King, M.A., Lizarraide, D., Bhatia, M.P., 2008 Fracture propagation to the base of the Greenland Ice Sheet during supraglacial lake drainage. Science 320, 778-781.

Denton, G.H., Hughes, T.J., 2002. Reconstruction of the Ross ice drainage system, Antarctica, at the last glacial maximum. Geogr. Ann. Ser. A Phys. Geogr. 82, 143-166.

Domack, E.W., Jacobson, E.A., Shipp, S., Anderson, J.B., 1999. Late Pleistocene-Holocene retreat of the West Antarctic Ice-Sheet system in the Ross Sea: part 2. Sedimentologic and stratigraphic signature. Geol. Soc. Am. Bull. 111, 1517-1536.
Drewry, D.J., 1983. Antarctica: Glaciological and Geophysical and Geophysical Folio. University of Cambridge Scott Polar Research Institute, Cambridge, United Kingdom, (9 pp.)

Engelhardt, H., Kamb, B., 1998. Basal sliding of Ice Stream B, West Antarctica. J. Glaciol. 44, 223-230.

Evans, D.J.A., Phillips, E.R., Hiemstra, J.F., Auton, C.A., 2006. Subglacial till: formation, sedimentary characteristics and classification. Earth Sci. Rev. 78, 115-176.

Fahnestock, M.A., Scambos, T.A., Bindschadler, R.A., Kvaran, G., 2000. A millennium of variable ice flow recorded by the Ross Ice Shelf, Antarctica. J. Glaciol. 46, 652-664.

Grindley, G.W., Warren, G., 1964. Stratigraphic nomenclature and correlation in the western part of Ross Sea. In: Adie, R.J. (Ed.), Antarctic Geology. North Holland Publishing Company, Amsterdam, pp. 314-333.

Gunn, B.M., Warren, G., 1962. Geology of Victoria Land between the Mawson and Mulock Glaciers, Antarctica. N. Z. Geol. Surv. Bull. 71, 1-157.

Hambrey, M.J., Glasser, N.F., 2012. Discriminating glacier thermal and dynamic regimes in the sedimentary record. Sediment. Geol. 251-252, 1-33.

Hart, J.K., 2006. An investigation of subglacial processes at the microscale from Briksdalsbreen, Norway. Sedimentology 53, 125-146.

Henrys, S.A., Wilson, T.J., Whittaker, J., Fielding, C.R., Hall, J., Naish, T.R., 2007. Tectonic history of mid-Miocene to present Southern Victoria Land Basin, inferred from seismic stratigraphy in McMurdo Sound, Antarctica. In: Cooper, A.K., Raymond, C.R. (Eds.), Antarctica: A Keystone in a Changing World - Online Proceedings for the Tenth International Symposium on Antarctic Earth Sciences. US Geological Survey Open-File Report 2007-1047, Short Research Paper 049 (4 pp.).

Hiemstra, J.F., Rijsdijk, K.F., 2003. Observing artificially induced strain: implications for subglacial deformation. J. Ouat. Sci. 18, 373-383.

Hiemstra, J.F., Rijsdijk, K.F., Evans, D.J.A., van der Meer, J.J.M., 2005. Integrated micro- and macro-scale analyses of Last Glacial Maximum Irish Sea diamicts from Abermawr and Traeth y Mwnt, Wales, UK. Boreas 34, 61-74.

Hoffman, M.J., Catania, G.A., Neumann, T.A., Andrews, L.C., Rumrill, J.A., 2011. Links between acceleration, melting, and supraglacial lake drainage of the western Greenland Ice Sheet. J. Geophys. Res. Earth Surf. 116, F4.

Holland, D.M., Thomas, R.H., de Young, B., Ribergaard, M.H., Lyberth, B., 2008. Acceleration of Jakobshaven Isbrae triggered by warm subsurface ocean waters. Nat. Geosci. 1, 659-664.

Howat, I.M., Domack, E.W., 2003. Reconstructions of western Ross Sea palaeo-ice stream grounding zones from high-resolution acoustic stratigraphy. Boreas 32, 56-75

Hughes, T., 1977. West Antarctic ice streams. Rev. Geophys. Space Phys. 15, 1-46.

Iken, A., Echelmeyer, K., Harrison, W., Funk, M., 1993. Mechanisms of fast flow in Jakobshavns Isbræ, West Greenland. I: measurements of temperature and water level in deep boreholes. J. Glaciol. 39, 15-25.

Joughin, I., Tulaczyk, S., MacAyeal, D.R., Engelhardt, H., 2004. Melting and freezing beneath the Ross ice streams, Antarctica. J. Glaciol. 50, 96-108.

Khatwa, A., Tulaczyk, S., 2001. Microstructural interpretations of modern and Pleistocene subglacially deformed sediments: the relative role of parent material and subglacial processes. J. Quat. Sci. 16, 507-517.

Kilfeather, A.A., Ó Cofaigh, C., Dowdeswell, J.A., van der Meer, J.J.M., Evans, D.J.A., 2010. Micromophological characteristics of glacimarine sediments: implications for distinguishing genetic processes of massive diamicts. Geo-Mar. Lett. 30, 77-97.

Kjær, K.H., 1999. Mode of subglacial transport deduced from till properties, Mýrdalsjökull, Iceland. Sediment. Geol. 128, 271-292.

Kretz, R., 1983. Symbols for rock forming minerals. Am. Mineral. 68, 277-279.

Larsen, N.K., Piotrowski, J.A., Christoffersen, P., Menzies, J., 2006. Formation and deformation of basal till during a glacier surge; Elisebreen, Svalbard. Geomorphology 81, 217-234.

Levy, R., Cody, R., Crampton, J., Fielding, C., Golledge, N., Harwood, D., Henrys, S., McKay, R., Naish, T, Ohneiser, C., Wilson, G. Wilson, T.,Winter, D., 2012. Late Neogene climate and glacial history of the southern Victoria Land coast from integrated drill core, seismic and outcrop data. Glob. Planet. Chang. 80-81, 61-84.

Lewis, A.R., Marchant, D.R., Ashworth, A.C., Hemming, S.R., Machlus, M.L., 2007. Major middle Miocene global climate change: evidence from East Antarctica and the Transantarctic Mountains. Geol. Soc. Am. Bull. 119, 1449-1461. http://dx.doi.org/10. 1130/B26134.1

Licht, K.J., Palmer, E.F., 2013. Erosion and transport by Byrd Glacier, Antarctica during the Last Glacial Maximum. Quat. Sci. Rev. 62, 32-48.

Licht, K.J., Dunbar, N.W., Andrews, J.T., Jennings, A.E., 1999. Distinguishing subglacial till and glacial marine diamictons in the western Ross Sea, Antarctica: implications for a Last Glacial Maximum grounding line. Geol. Soc. Am. Bull. 111, 91-103.

Licht, K.J., Lederer, J.R., Swope, R.J., 2005. Provenance of LGM glacial till (sand fraction) across the Ross embayment, Antarctica. Quat. Sci. Rev. 24, 1499-1520.

Mahaney, W.C. 1995. Glacial crushing, weathering and diagenetic histories of quartz grains inferred from scanning electron microscopy. In: Menzies, J. (Ed.), Modern Glacial Environments - Processes, Dynamics and Sediments, Glacial Environments. Butterworth-Heinemann, Oxford, pp. 487-506.

Mahaney, W.C., 2002. Atlas of Sand Grain Surface Textures and Applications. Oxford University Press, Oxford, (237 pp.)

McKay, R., Browne, G., Carter, L., Cowan, E., Dunbar, G., Krissek, L., Naish, T., Powell, R., Reed, J., Talarico, F., Wilch, T., 2009. The stratigraphic signature of the late Cenozoic Antarctic Ice Sheets in the Ross Embayment. Geol. Soc. Am. Bull. 121, 1531-1561.

McKay, R., Naish, T., Powell, R., Barett, P., Scherer, R., Talarico, F., Kyle, P., Monien, D., Kuhn, G., Jackolski, C., Williams, T., 2012. Pleistocene variability of Antarctic Ice Sheet extent in the Ross Embayment. Quat. Sci. Rev. 34, 93-112.

Menzies, J., 2000. Micromorphological analyses of microfabrics and microstructures indicative of deformation processes in glacial sediments. In: Maltman, A.J., Hubbard, B., Hambrey, M.J. (Eds.), Deformation of Glacial Materials. Geological Society of London, Special Publications, 176, pp. 245-257. 
Menzies, J., Zaniewski, K., 2003. Microstructures within a modern debris flow deposit derived from Quaternary glacial diamicton - a comparative micromorphological study. Sediment. Geol. 157, 31-48.

Menzies, J., van der Meer, J.J.M., Rose, J., 2006. Till - a glacial “tectomict”, a microscopic examination of a till's internal architecture. Geomorphology 75, 172-200.

Menzies, J., van der Meer, J.J.M., Domack, E., Wellner, J.S., 2010. Micromorphology: as a tool in the detection, analyses and interpretation of (glacial) sediments and manmade materials. Proc. Geol. Assoc. 121, 281-292.

Mosola, A.B., Anderson, J.B., 2006. Expansion and rapid retreat of the West Antarctic Ice Sheet in eastern Ross Sea: possible consequence of over-extended ice streams? Quat. Sci. Rev. 25, 2177-2196.

Naish, T., Powell, R., Levy, R., 2007. Studies from the ANDRILL, McMurdo Ice Shelf Project, Antarctica, initial science report on AND-1B. Terra Antarct. 14, 328.

Naish, T., Powell, R., Levy, R., Wilson, G., Scherer, R., Talarico, F., Krissek, L., Niessen, F., Pompilio, M., Wilson, T., Carter, L., DeConto, R., Huybers, P., McKay, R., Pollard, D. Ross, J., Winter, D., Barrett, P., Browne, G., Cody, R., Cowan, E., Cramption, J., Dunbar, G., Dunbar, N., Florindo, F., Gebhardt, C., Graham, I., Hannah, M., Hansaraj, D., Harwood, D., Helling, D., Henrys, S., Hinnov, L., Kuch, G., Kyle, P., Läufer, A., Maffioli, P., Magens, D., Mandernack, K., McIntosh, W., Millan, C., Morin, R., Ohneiser, C., Paulsen, T., Persico, D., Raine, I., Reed, J., Riesselman, C., Sagnotti, L., Schmitt, D., Sjunneskog, C., Strong, P., Taviani, M., Vogel, S., Wilch, T., Williams, T., 2009. Obliquity-paced Pliocene West Antarctic Ice Sheet oscillations. Nature 458, 322-329.

Niessen, F., Magens, D., Gebhardt, A.C., the ANDRILL-MIS Science Team, 2007. Physical properties of the AND-1B core, ANDRILL McMurdo Ice Shelf Project, Antarctica. Terra Antarct. 14, 155-166.

Ó Cofaigh, C., Dowdeswell, J.A., Allen, C.S., Hiemstra, J.F., Pudsey, C.J., Evans, J., Evans, D.J.A., 2005. Flow dynamics and till genesis associated with a marine-based Antarctic palaeo-ice stream. Quat. Sci. Rev. 24, 709-740.

Phillips, E., Merritt, J., Auton, C., Golledge, N., 2007. Microstructures in subglacial and proglacial sediments: understanding faults, folds and fabrics, and the influence of water on the style of deformation. Quat. Sci. Rev. 26, 1499-1528.

Piotrowski, J.A., Larsen, N.K., Menzies, J., Wysota, W., 2006. Formation of subglacial till under transient bed conditions: deposition, deformation, and basal decoupling under a Weichselian ice sheet lobe, central Poland. Sedimentology 53, 83-106.

Pollard, D., DeConto, R.M., 2009. Modelling West Antarctic Ice Sheet growth and collapse through the past five million years. Nature 458, 329-332.

Pompilio, M., Dunbar, N., Gebhardt, A.C., Helling, D., Kuhn, G., Kyle, P., McKay, R., Talarico, F., Tulaczyk, S., Voge, S., Wilch, T., the ANDRILL-MIS Science Team, 2007. Petrology and geochemistry of the AND-1B core, ANDRILL McMurdo Ice Shelf Project, Antarctica. Terra Antarct. 14, 255-288.

Salvi, C., Busetti, M., Marinoni, L., Brambati, A., 2006. Late Quaternary glacial marine to marine sedimentation in the Pennell Trough (Ross Sea, Antarctica). Palaeogeogr. Palaeoclimatol. Palaeoecol. 231, 199-214.

Scherer, R., Hannah, M., Maffioli, P., Persico, D., Sjunneskog, C., Strong, C.P., Taviani, M. Winter, D., the ANDRILL-MIS Science Team, 2007. Palaeontologic characterisation and analysis of the AND-1B core, ANDRILL McMurdo Ice Shelf Project, Antarctica. Terra Antarct. 14, 223-254.

Shipp, S., Anderson, J.B., Domack, E.W., 1999. Late Pleistocene-Holocene retreat of the West Antarctic ice-sheet system in the Ross Sea: part 1. Geophysical results. Geol. Soc. Am. Bull. 111, 1486-1516.

Simpson, A.L., Cooper, A.F., 2002. Geochemistry of the Darwin Glacier region granitoids, southern Victoria Land. Antarct. Sci. 14, 425-426.
Skinner, D.N.B., 1982. Stratigraphy and structure of lower grade metasediments of Skelton Group, McMurdo Sound - does Teall greywacke really exist? In: Craddock, C. (Ed.), Antarctic Geoscience. University of Wisconsin Press, Madison, pp. 555-563.

Smellie, J.L., Rocchi, S., Wilch, T.I., Gemelli, M., Di Vincenzo, G., McIntosh, W., Dunbar, N. Panter, K., Fargo, A., 2013. Glaciovolcanic evidence for a polythermal Neogene East Antarctic Ice Sheet. Geology. http://dx.doi.org/10.1130/G34787.1.

Sterns, L.A., 2011. Dynamics and mass balance of four large East Antarctic outlet glaciers Ann. Glaciol. 52, 116-126.

Stump, E., 1995. The Ross Orogen of the Transantarctic Mountains. Cambridge University Press, (284 pp.).

Talarico, F., Sandroni, S., 2009. Provenance signatures of the Antarctic Ice Sheets in the Ross Embayment during the Late Miocene to Early Pliocene: the ANDRILL AND-1B core record. Glob. Planet. Chang. 69, 103-123.

Talarico, F.M., McKay, R.M., Powell, R.D., Sandroni, S., Naish, T., 2010. Late Cenozoic oscillations of Antarctic ice sheets revealed by provenance of basement clasts and grain detrital modes in ANDRILL core AND-1B. Glob. Planet. Chang. 96-97, 23-40. http:// dx.doi.org/10.1016/j.gloplacha.2009.12.002.

Tulaczyk, S., Kamb, B., Scherer, R.P., Engelhardt, H.F., 1998. Sedimentary processes at the base of a West Antarctic ice stream: constraints from textural and compositional properties of subglacial debris. J. Sediment. Res. 68, 487-496.

Tulaczyk, S., Kamb, B., Engelhardt, H.F., 2001. Estimates of effective stress beneath a modern West Antarctic ice stream from till preconsolidation and void ratio. Boreas 30, 101-114.

van der Meer, J.J.M., 1993. Microscopic evidence of subglacial deformation. Quat. Sci. Rev. 12, 553-587.

van der Meer, J.J.M., 1997. Particle and aggregate mobility in till: microscopic evidence of subglacial processes. Quat. Sci. Rev. 16, 827-831.

van der Meer, J.J.M., Menzies, J., 2011. The micromorphology of unconsolidated sediments. Sediment. Geol. 238, 213-232.

van der Meer, J.J.M., Menzies, J., Rose, J., 2003. Subglacial till: the deforming glacier bed. Quat. Sci. Rev. 22, 1659-1685.

Van Hoesen, J.G., Orndorff, R.L., 2004. A comparative SEM study on the micromorphology of glacial and nonglacial clasts with varying age and lithology. Can. J. Earth Sci. 41, 1123-1139.

Vos, K., Vandenberghe, N., Elsen, J., 2014. Surface textural analysis of quartz grains by scanning electron microscopy (SEM): from sample preparation to environmental interpretation. Earth Sci. Rev. 128, 93-104.

Weiler, C.S., Licht, K., 2011. Polymict frequencies in LGM till as a proxy for paleo icestream flow in the Ross Embayment, Antarctica (abstract). Geol. Soc. Am. Abstr. Programs 43, 131.

Wilson, G.S., Levy, R.H., Naish, T.R., Powell, R.D., Florindo, F., Ohneiser, C., Sagnotti, L., Winter, D.M., Cody, R., Henrys, S., Ross, J., Krissek, L., Niessen, F., Pompilio, M., Scherer, R., Alloway, B.V., Barrett, P., Brachfeld, S., Browne, G., Carter, L., Cowan, E. Crampton, J., DeConto, R.M., Dunbar, G., Dunbar, N., Dunbar, R., von Eynatten, H., Gebhardt, C., Giorgetti, G., Graham, I., Hannah, M., Hansaraj, D., Harwood, D. Hinnov, L., Jarrard, R.D., Joseph, L., Kominz, M., Kuhn, G., Kyle, P., Läufer, A., McIntosh, W.C., McKay, R., Maffioli, P., Magens, D., Millan, C., Monien, D., Morin, R., Paulsen, T., Persico, D., Pollard, D., Raine, I.J., Riesselman, C., Sandroni, S., Schmitt, D., Sjunneskog, C., Strong, C.P., Talarico, F., Taviani, M., Villa, G., Vogel, S., Wilch, T., Williams, T., Wilson, T.J., Wise, S., 2012. Neogene tectonic and climatic evolution of the Western Ross Sea, Antarctica - chronology of events from the AND-1B drill hole. Glob. Planet. Chang. 96-97, 189-203. 